\title{
Classification of the present pharmaceutical agents based on the possible effective mechanism on the COVID-19 infection
}

\author{
Maryam Amini Pouya ${ }^{1} \cdot$ Seyyedeh Maryam Afshani ${ }^{2} \cdot$ Armin Salek Maghsoudi $^{3} \cdot$ Shokoufeh Hassani ${ }^{3,4}$ (i) \\ Kayvan Mirnia ${ }^{5}$
}

Received: 18 June 2020 / Accepted: 14 July 2020 / Published online: 30 July 2020

(C) Springer Nature Switzerland AG 2020

\begin{abstract}
Objectives There are several types of research on the COVID-19 disease which have been conducting. It seems that prevailing over the pandemic would be achieved only by mastering over the virus pathophysiology. We tried to categorize the massive amount of available information for useful interpretation.

Evidence acquisition We searched databases with different keywords and search strategies that focus on virulence and pathophysiology of COVID-19. The present review has aimed to gather and categorize all implemented drugs based on the susceptible virulence mechanisms, and the pathophysiological events in the host cells, discussing and suggesting treatments.

Results As a result, the COVID-19 lifecycle were categorized as following steps: "Host Cell Attachment" which is mainly conducted with $\mathrm{ACE}_{2}$ receptors and TMPRSS2 from the host cell and Spike (S) protein, "Endocytosis Pathway" which is performed mainly by clathrin-mediated endocytosis, and "Viral Replication" which contains translation and replication of RNA viral genome. The virus pathogenicity is continued by "Inflammatory Reactions" which mainly caused moderate to severe COVID-19 disease. Besides, the possible effective therapeutics' mechanism and the pharmaceutical agents that had at least one experience as a preclinical or clinical study on COVID-19 were clearly defined.

Conclusion The treatment protocol would be occasional based on the stage of the infection and the patient situation. The cocktail of medicines, which could affect almost all mentioned stages of COVID-19 disease, might be vital for patients with severe phenomena.
\end{abstract}

Keywords Coronaviruses $\cdot$ COVID-19 $\cdot$ SARS-CoV-2 $\cdot$ Pandemic $\cdot$ Pharmaceutical agents $\cdot$ Possible treatments $\cdot$ Drug classification

Shokoufeh Hassani and Kayvan Mirnia contributed equally to this work.

Shokoufeh Hassani

shokoufehasani@gmail.com

Kayvan Mirnia

kmirnia@sina.tums.ac.ir

1 Department of Pharmaceutics, School of Pharmacy, Tehran University of Medical Sciences, Tehran, Iran

2 Department of Pharmacoeconomics, School of Pharmacy, Tehran University of Medical Sciences, Tehran, Iran

3 Department of Toxicology and Pharmacology, School of Pharmacy, Tehran University of Medical Sciences, Tehran, Iran

4 Toxicology and Diseases Group (TDG), Pharmaceutical Sciences Research Center (PSRC), the Institute of Pharmaceutical Sciences (TIPS), Tehran University of Medical Sciences, Tehran, Iran

5 Children's Medical Center, Tehran University of Medical Sciences, Tehran, Iran

\section{Introduction}

CoVs (coronaviruses) are viruses with single-stranded RNA (30 kb genomes) and large enveloped particles (60-140 nm), which affect human and animal health [1-3]. Three remarkable ones cause respiratory and enteric disease with severe comorbidity and mortality in some cases $[2,4,5]$. SARS (severe acute respiratory syndrome) was the first one, which emerged in southern China and spread among 29 countries from November 2002 until July 2003 with 8098 patients, including 774 death. MERS (Middle East respiratory syndrome) was the second one, which appeared in Saudi Arabia and caused 2458 patients to be infected, leading to 848 death in 27 countries until July 2019 [2].In Wuhan, Hubei province, China, there were reports of pneumonia emergent with unknown causes in December 2019 [6]. After that, the novel CoV (SARS-CoV-2, 
known as COVID-19) was separated from pneumonia patients on January 7, 2020, as the third imperative and seventh known ones [2, 7]. COVID-19 infected 571 individuals in 25 provinces in China until January 22, 2020, which rapidly increased to 44,672 confirmed COVID-19 infection (62\% of total 72,314 susceptible cases) through February 2020, reported by Chinese Center for Disease Control and Prevention [8, 9].All the three notable CoVs are emerged by zoonotic transmission, likely from bats [9]. Contact with droplets, which dispersed from, infected patient's mouth and nose, is identified as the leading cause of person-to-person contamination [10]. World Health Organization (WHO) announced on March 11, 2020, that the occurrence of COVID-19 is considered a pandemic with more than 118,000 infected individuals, which led to 4292 deaths in 114 countries [11].

The main initial symptoms of an infected individual were fever (98.6\%), fatigue (69.6\%), dry cough (59.4\%), myalgia (34.8\%), and dyspnea (34.2\%) in a report of 138 patients in the hospital in China [12]. Generally, children without underlying diseases appeared to have a mild disease [13]. Experts declare that the incubation period of COVID-19 is 14-day duration before the initial symptoms [14]. A Chest CT scan is a helpful tool for early diagnosis in susceptible individuals [15]. The ground-glass opacification with occasional consolidation is the main feature of patients' chest CT [16]. After confirmation of the diagnosis, treatment became the main challenge for clinicians. During the first days there was no strategy for treatment, so based on available drugs medication continued. On May 01, 2020, the U.S. Food and Drug Administration permits using Remdesivir antiviral drugs for the treatment of confirmed COVID-19 severe disease in adults and children [17, 18]. But this was not the end of the way. Remdesivir can decrease the stay in the hospital, on the other hand, the virus shows different manifestations that require various strategies for treatment.

Therefore, as finding an appropriate treatment protocol is the fundamental solution for overcoming the COVID-19, we searched databases with different keywords and search strategies that focus on virulence and pathophysiology of COVID19. As a result, we explained the virus pathogenicity, the therapy mechanism, and the drug options. According to the tables, we gathered the pharmaceutical agents that had at least one experience as a preclinical or human clinical study on COVID-19. The drugs implemented in the clinic are reviewed in the text and drugs passing their human clinical trials are mentioned in the table. The mechanisms of all of the drugs are mentioned in the table, so this can give an insight to the researchers for choosing a good combination for therapy.

\section{Method}

An aimed literature review accomplished to classification of the present pharmaceutical agents on COVID-19. We searched original articles published in the English language from Jan 2019 to April 2020, from the online databases and related websites as WHO and ClinicalTrials.gov, PubMed/ MEDLINE, Google Scholar, Web of Science, along with assessing all the references of the articles retrieved. We used different keywords that focus on virulence, pathophysiology, and drugs implemented in COVID-19. The authors evaluated the relevance of the references firstly by reading the titles and the abstracts. Then the full papers of the selected articles and their relevant references were derived and read thoroughly. Also, it appears that there is a relationship between some drugs previously used against SARS-CoV and MERS-CoV and the COVID-19 life cycle. So, we searched studies published with in vitro and in vivo activity and clinical experiences to suggest possible treatment options for COVID-19. The searched terms were COVID-19 OR Coronavirus OR SARS-CoV-2 OR SARS-CoV OR MERS-CoV. For chosen drugs for the COVID-19 life cycle, clinical trials (including those recruiting, not yet recruiting, active, and completed) with searching on ClinicalTrials.gov mentioned in the tables.

\section{COVID-19 life cycle}

It can be categorized as 1) "Host Cell Attachment" which is mainly conducted with $\mathrm{ACE}_{2}$ (angiotensin-converting enzyme-2) receptors and TMPRSS2 (transmembrane protease serine-2) from the host cell and Spike (S) protein from the virus particle, 2) "Endocytosis Pathway" which is performed mainly by clathrin-mediated endocytosis, and 3) "Viral Replication" which contains translation and replication of RNA viral genome.

The virus particle includes a lipid envelope [19] structural proteins encompass envelope (E), membrane (M), surface glycoprotein projections called Spike (S) [20], and nucleocapsid $(\mathrm{N})$ proteins. COVID-19 virus particles bind to the $\mathrm{ACE}_{2}$ receptors on human cells via Spike proteins- homotrimer of $\mathrm{S}$ proteins with a high affinity comparing to SARS-CoV (10- to 20-fold higher) [21, 22] (Fig. 1) and mainly lead to endocytosis via "clathrin-mediated endocytosis" pathway [23, 24]. The virus particle endosome would be followed by either "Late endosome/Lysosome" formation or "Autophagy" via DMV (double-membrane vesicle) and Autolysosome creation, but there is some controversy about the Autophagy [25]. The lysosomal function needs acidic $\mathrm{pH}$ for injecting the viral genome into the host cell (Fig. 2).Nonstructural proteins contain polyproteins, nucleoproteins, RNA polymerase, 3CL (3-chymotrypsinlike) protease, PL (papain-like) protease, and helicase, which are produced after RNA genome expression in the host cell for forming the new virus particles and infecting other cells [26] (Fig. 3). 


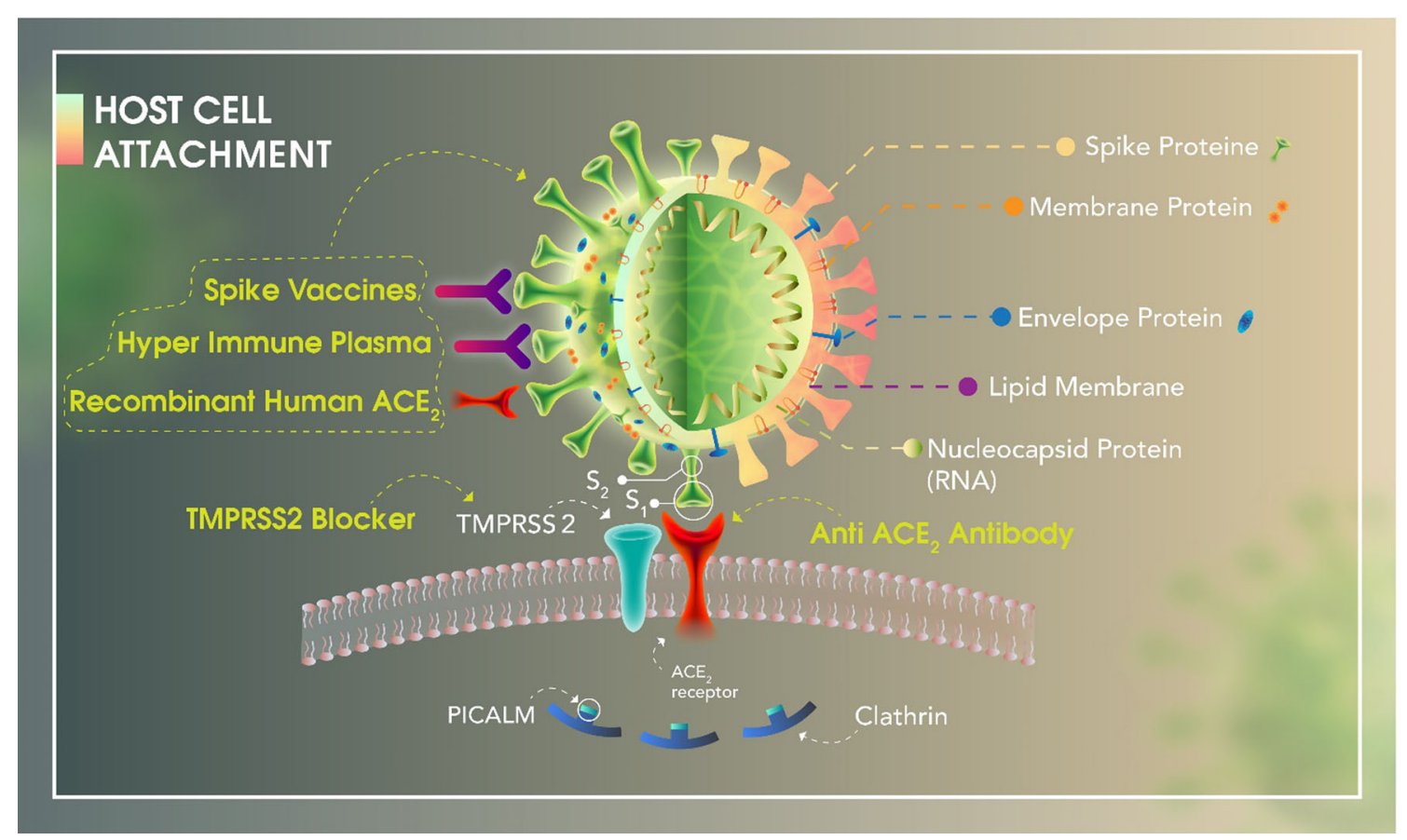

Fig. 1 Host Cell Attachment, The COVID-19 structural proteins include envelope (E), membrane (M), Spike (S), and nucleocapsid $(N)$ proteins. S proteins bind the $\mathrm{ACE}_{2}$ (angiotensin-converting enzyme-2) receptors with $\mathrm{S}_{1}$ (subunit 1 ). The activity of proteases such as TMPRSS2 (transmembrane protease serine-2) has a crucial role in this step. The

\section{Host cell attachment}

As it is briefly explained, COVID-19 virus particles target the $\mathrm{ACE}_{2}$ receptors on human cells via $\mathrm{S}$ proteins for endocytosis and infecting the host cell [21,24]. Also, it seems that COVID-19 might need the TMPRSS2 and other related proteases for host cell entry as it has a crucial role in S protein activation for membrane fusion [27, 28] (Fig. 1) and enhance the $\mathrm{ACE}_{2}$ activity for viral entry [29]. Notably, all $\mathrm{ACE}_{2}$-represented pulmonary cells are also TMPRSS2- positive [29], so the approved inhibitor might be a part of COVID-19 therapy [28]. We can categorize the "Host Cell Attachment" inhibitors as potential treatments into the following groups:

\section{Spike protein blockers}

As the $\mathrm{S}$ proteins have a crucial role in initiating the pathogenicity, it can be neutralized by plasma antibodies from the cured COVID-19 patients (approved by the US Food and Drug Administration in severe cases) [30, 31], IVIG (intravenous immunoglobulin-passive immunity) [32], recombinant human $\mathrm{ACE}_{2}$, or $\mathrm{S}$ protein-based vaccination (active immunity) [33]. Improvement in clinical status of 5 patients with severe COVID-19 disease and acute respiratory distress syndrome (ARDS), was reported in an uncontrolled case series after administration of neutralizing antibody from convalescent plasma [34]. The vaccine for COVID-19 should simulate clathrin proteins, PICALM (phosphatidylinositol binding clathrin assembly protein) and $\mathrm{S}_{2}$ (subunit 2) would participate in the next stage of the virus life cycle. The pharmaceutical agents which could interrupt the COVID-19 binding to the host cell membrane are exhibited in yellow color based on the mechanism and the specific site of action

the exterior configuration of spike since it is responsible for virus-host cell interaction [8]. The development of an $S_{1}$ subunit protein-based vaccine may rely on the fact that $\mathrm{ACE}_{2}$ is the COVID-19 receptor. Cell lines that facilitate viral replication in the presence of $\mathrm{ACE}_{2}$ may be most efficient in largescale vaccine production [33].

\section{$\mathrm{ACE}_{2}$ reversible blockers}

There are several cells with high levels of $\mathrm{ACE}_{2}$ expression, which could be a potential target for COVID-19 including $\mathrm{AEC}_{\mathrm{II}}$ (alveolar epithelial type II cells) in the lung, esophagus upper and stratified epithelial cells, absorptive enterocytes from ileum and colon, cholangiocytes, myocardial cells, kidney proximal tubule cells, endothelial cells of the liver, and bladder urothelial cells $[21,35,36]$. Despite $\mathrm{ACE}_{2}$ receptors are more significant in the heart, testis, bladder, kidney, gallbladder, adipose tissue, and intestine comparing to the lungs [22], lungs are a more susceptible target for the COVID-19. L Bao et al., study showed the histopathology of human- $\mathrm{ACE}_{2}$ transgenic mice, which was infected by inhalation of COVID19 virus particles, expressed the migration of remarkable amounts of monocytes and lymphocytes in the alveolar interstitial and macrophages accumulation in alveolar cavities causing interstitial pneumonia. Besides, there were no outstanding histopathologic finding in any other organs such as liver, myocardium, gallbladder kidney, intestine, and testis 
Fig. 2 Endocytosis Pathway, This step initiates by viral particles clathrin-dependent endocytosis. The virus particles are now cargoes in the "Early

Endosome." Some proteins, like PICALM (phosphatidylinositol binding clathrin assembly protein), are essential for maturation of early endosome, especially its curvature and regulation of clathrin-dependent endocytosis rate. The "Late Endosome" is created by excluding the membrane receptors such as $\mathrm{ACE}_{2}$ (angiotensin-converting enzyme2 ) from the early endosome. Then lysosome is fused to late endosome for starting $\mathrm{pH}$-dependent degradation. The lysosomal function needs acidic $\mathrm{pH}$ for injecting the viral genome into the host cell. FURIN proteases such as

Cathepsin B \& L are responsible for cutting Spike into $S_{1}$ and $S_{2}$ subunits from the FURIN cleavage site. After cutting the $S_{2}$ and revealing the $S_{1}$ subunit, the viral membrane could fuse the Late Endosome membrane and release the nucleocapsid protein into the host cell. The pharmaceutical agents which could interrupt the COVID-19 endocytosis pathway are exhibited in yellow color based on the mechanism and the specific site of action

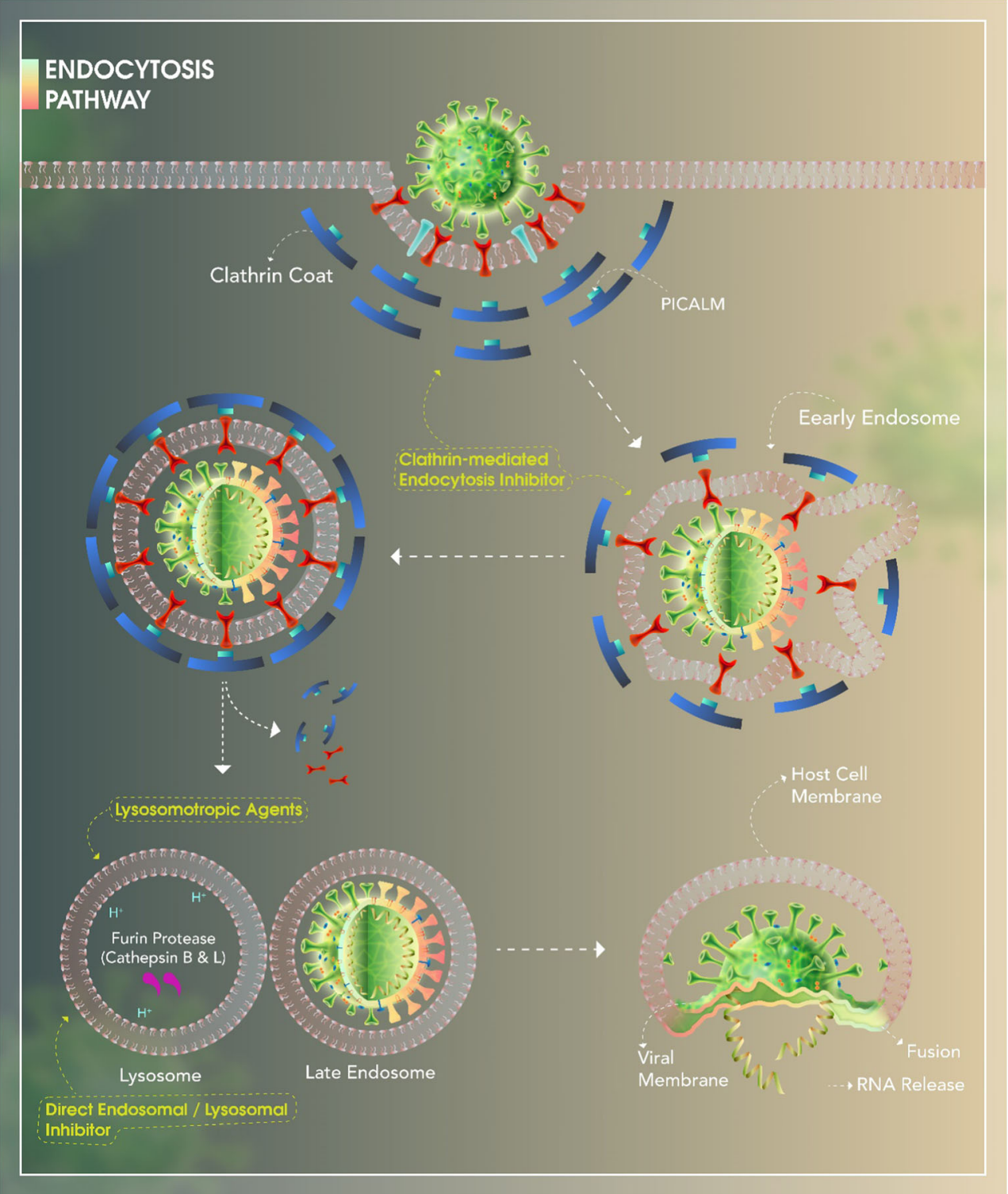

[37]. Another animal model on murine, conducted with SARS-CoV infection, indicated the downregulation of $\mathrm{ACE}_{2}$ receptors followed by angiotensin II accumulation, pulmonary vascular permeability, and finally, pulmonary edema [38]. This mechanism also suggested the occurrence of fulminant myocarditis [39]. As previously known, the downregulation of $\mathrm{ACE}_{2}$ receptors indicated the severe lung injury in mice, which are infected by SARS-CoV [33]. Recombinant human $\mathrm{ACE}_{2}$ can also prevent $\mathrm{ACE}_{2}$ down-regulation [33].

Although Losartan, as an $\mathrm{ACE}_{2}$ receptor antagonist, has the potential for mitigation of lung injury [38, 39], there is controversy regarding the use of RAS antagonists, including ACE inhibitors and ARBs in COVID-19 patients [38]. Clinical studies have been conducting to prove the efficacy of losartan (NCT04312009) and or to clarify the suspected risk factor of using RAAS (renin-angiotensin-aldosterone system) antagonists in individuals with severe COVID-19 (NCT04318418) (Table 1).

The higher chronic expression of $\mathrm{ACE}_{2}$ receptors explains this controversy, which could affect prone patients with a higher risk of severe COVID-19. There is a report regarding the beneficial use of $\mathrm{ACE}_{2}$-modulating medicines (ACE inhibitors or ARBs) in patients with concomitant chronic disorders such as hypertension, or diabetes, who are receiving $\mathrm{ACE}_{2}$-increasing drugs [40] like thiazolidinediones and ibuprofen, however, recent studies in clinics recommend ibuprofen usage if there is no alleviation after a full dose of acetaminophen [40]. Some experts have recommended avoiding the implementation of nonsteroidal anti-inflammatory drugs (NSAIDs) in the early course of disease due to its negative impact on outcome [41]. Other $\mathrm{ACE}_{2}$ activators are xanthenone, which has 


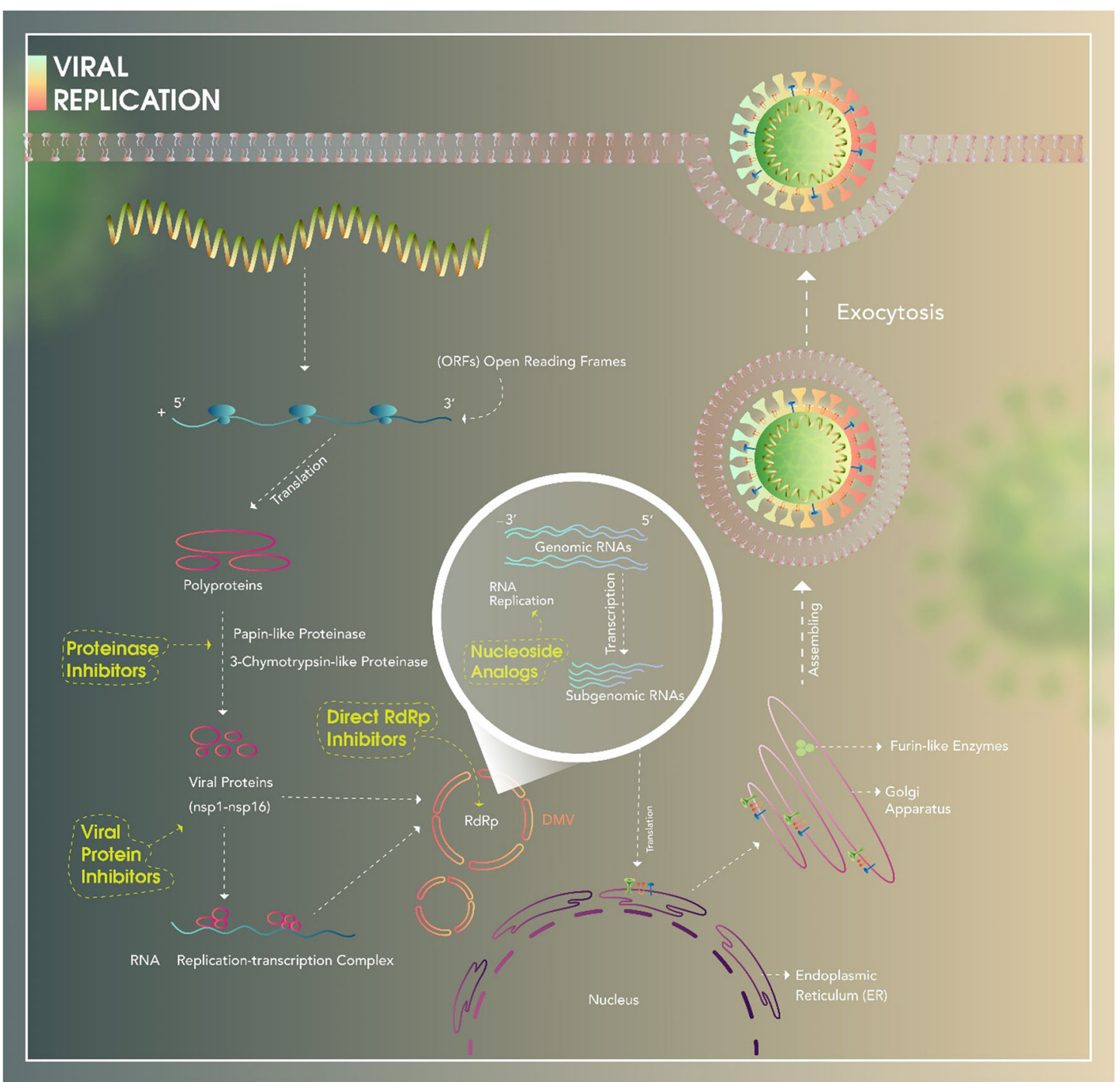

Fig. 3 Viral Replication, COVID-19 disassemble to release the RNA genome after the intra-cellular entrance. The genome which contains $5^{\prime}$ methylated caps and 3'-polyadenylated tails is arranged in the order of 5'. The open reading frames (ORFs) are translated into polyproteins in the cytoplasm. The produced polyproteins are cleaved by papain-like proteinase and $3 \mathrm{C}$-like proteinase to produce sixteen non-structural proteins (NSP1-NSP16), which develop RNA Replication-Transcription Complex. The virus RNA replication is conducted by a viral enzyme called RNA-dependent RNA polymerase (RdRp) in the doublemembrane vesicles (DMV) which is derived from the endoplasmic reticulum (ER). Then the genomic RNAs are transcribed into subgenomic RNAs and translated. As a result, structural proteins are synthesized and assembled into the nucleocapsid and viral envelope with ER-Golgi coordination. FURIN-like enzymes form the bound between $S_{1}$ and $S_{2}$ subunit in the assembling stage in the Golgi. Finally, the new virions are released by exocytosis into the extracellular compartment. The pharmaceutical agents which could interrupt the COVID-19 replication are exhibited in yellow color based on the mechanism and the specific site of action. +: positive-stranded RNA, -: negative-stranded RNA

in one small clinical assessment in China, respectively. It is also notable that $7 \%$ were died only due to fulminant myocarditis [43]. However, Asian ethnicity is outstanding for the occurrence of high-degree AV block due to myocarditis in comparison with other populations $(8.1 \%$ vs. $1 \%)$ [32]. We do not know the prevalence of fulminant myocarditis in other populations as a cause of death. Fortunately, some reports indicated that early use of IVIG before ECMO (extracorporeal membrane oxygenation) [32] and steroids could prevent mortality due to myocarditis [44]. 
Table 1 The definition of molecules that are assumed to be effective in the disruption of the COVID-19 Host Cell Attachment

\begin{tabular}{|c|c|c|c|c|}
\hline Drug name & Category & $\begin{array}{l}\text { Mechanism on } \\
\text { COVID-19 }\end{array}$ & $\begin{array}{l}\text { Preclinical } \\
\text { studies }\end{array}$ & Human clinical studies \\
\hline $\begin{array}{l}\text { Hyperimmune } \\
\text { plasma }\end{array}$ & Immunoglobulin & $\begin{array}{l}\text { Anti-infectious } \\
\text { (passive } \\
\text { immunity) }\end{array}$ & NR & $\begin{array}{l}\text { NCT04344977, NCT04350580, } \\
\text { NCT04333355, NCT04348656, } \\
\text { NCT04343261, NCT04340050, } \\
\text { NCT04343755 }\end{array}$ \\
\hline IVIG & Immunoglobulin & $\begin{array}{l}\text { Anti-infectious } \\
\quad \text { (passive } \\
\text { immunity) } \\
\text { [32] }\end{array}$ & NR & NCT04261426, NCT04264858 \\
\hline $\begin{array}{l}\text { Recombinant } \\
\text { human } \\
\mathrm{ACE}_{2}\end{array}$ & Soluble $\mathrm{ACE}_{2}$ & $\begin{array}{l}\text { - Virus particles } \\
\text { neutralizing } \\
\text { agent } \\
\text { - } \mathrm{ACE}_{2} \\
\text { down-- } \\
\text { regulation } \\
\text { preventer }\end{array}$ & $\begin{array}{c}\text { in vitro } \\
{[54]}\end{array}$ & $\begin{array}{l}\text { In ARDS patients was safe } \\
\text { (NCT04287686) }\end{array}$ \\
\hline Losartan & $\begin{array}{l}\text { RAAS } \\
\text { inhibition }\end{array}$ & $\begin{array}{l}\mathrm{ACE}_{2} \text { reversible } \\
\text { blocker }\end{array}$ & $\begin{array}{l}\text { Murine } \\
\text { model }\end{array}$ & $\begin{array}{l}\text { Disagreement about use in human: } \\
\text { NCT04312009, NCT04318418 }\end{array}$ \\
\hline $\begin{array}{l}\text { Camostat } \\
\text { Mesylate }\end{array}$ & $\begin{array}{l}\text { Serine protease } \\
\text { inhibitor }\end{array}$ & $\begin{array}{l}\text { TMPRSS2 } \\
\text { inhibitor }\end{array}$ & $\begin{array}{l}\text { in vitro } \\
\quad[28,50, \\
51]\end{array}$ & $\begin{array}{l}\text { NCT04321096 } \\
\text { NCT04338906 }\end{array}$ \\
\hline
\end{tabular}

$N R$, Not Reported; IVIG, Intravenous Immunoglobulin; $A C E_{2}$, Angiotensin-converting Enzyme-2; RAAS, Renin Angiotensin Aldosterone System; TMPRSS2, Transmembrane Protease Serine-2
Although, there are some clinical observations regarding mostly ALT/AST abnormal rising, seldom bilirubin level elevation (with about $14.8 \%$ to $53 \%$ ), and serum albumin increment in some severe cases. However, the causality between liver injury and COVID-19 remained unclear, since they had been taking lopinavir alone or plus ritonavir regimen that could damage the bile duct cells [35, 45]. Several studies discussed ACE gene polymorphism that it participates in risk elevation of related illnesses such as renal diseases, but its relationship remains uncertain for some other ones like diabetic nephropathy [46-48]. We reviewed literature about the role of ACE gene polymorphism in COVID-19 infection in European patients, which may influence the clinical manifestation [49].

Thus, theoretically, it seems that the respiratory damage would be the most critical implication of COVID-19, with about $86 \%$ incidence in cases of mortality [43]. There are some reasons for supporting these observations in the lung. First of all, the considerable surface area in alveoli, which makes it a vulnerable organ for inhaled virus particles. Secondly, the most $\mathrm{ACE}_{2}$-expressed cells $(83 \%)$ in the lungs are $\mathrm{AEC}_{\mathrm{II}}$, which can act as a reservoir for viral replication with significant levels of viral process-related genomes [33]. Therefore, experts recommend that pulmonary intervention in infected individuals would play a crucial role in the cocktail regimen treatment [33]. Table 1 shows some drugs that have the potential to be useful regarding the $\mathrm{ACE}_{2}$ role in COVID19 infectious.

\section{TMPRSS2 inhibitors}

One of the potential drugs with TMPRSS2 inhibitory activity is camostat mesylate (serine protease inhibitor), used for chronic pancreatitis in Japan, which has prevented casualty in SARS-infected mice [25, 33]. Also, Nafamostat mesylate a drug like camostat mesylate in japan has shown effectiveness in blocking COVID-19 entry into the host cells and particularly in lung cells in vitro, and the University of Tokyo is planning for clinical trials in April 2020 [50, 51].

There are some investigations regarding TMPRSS2 inhibition, such as Cbz (carboxybenzyl)-phosphono-Lys(OPh)2, which could prevent its activity irreversibly [52]. The local pulmonary formulation of some serine protease inhibitors (Aprotinin) prescribed for influenza in Russia, but there is no evidence yet for its effectiveness in COVID-19 [53].

\section{Endocytosis pathway}

As briefly discussed previously, this step initiates by viral particles clathrin-dependent endocytosis. The virus particles are now cargoes in the "Early Endosome." Some proteins, like PICALM (phosphatidylinositol binding clathrin assembly protein), are essential for maturation of early endosome, especially its curvature and regulation of clathrin-dependent endocytosis rate [3, 55] (Fig. 2). The "Late Endosome" is created by excluding the membrane receptors such as $\mathrm{ACE}_{2}$ from the early endosome. Then lysosome is fused to late endosome for 
starting $\mathrm{pH}$-dependent degradation $[25,56]$. FURIN proteases are one of the most imperative lysosomal cysteine proteases (such as Cathepsin B \& L), which are responsible for cutting Spike into $S_{1}$ and $S_{2}$ subunits from the FURIN cleavage site $[20,57]$. This cleavage is necessary for revealing the fusion peptide in $\mathrm{S}_{2}[59$ ], incorporation of virus and endosome/ lysosome membrane, releasing the COVID-19 genome into the host cytoplasm, and infection [25, 58, 59] (Fig. 2). Some others believe that infection could emerge directly via this fusion between the virus particle and cell membrane without endocytosis [60]. However, it is not the primary mechanism. Also, we know that the FURIN cleavage site in COVID-19 might cause higher pathogenicity and human-transmission rates comparing to the other $\mathrm{CoVs}[23,58]$. The FURIN proteases are abundant in lung cells so that the virus would be more infectious for the respiratory system [61]. There is some evidence for FURIN proteases inhibitory function of folic acid, which might contribute to the COVID-19 treatment protocol [62] (Table 2). We can categorize the endocytosis pathway inhibitors as potential treatments into the three leading groups as below [25].

\section{Clathrin-mediated endocytosis inhibitors}

Studies show the effectiveness of some drugs against COVID19, such as chloroquine (by reducing PICALM) [3]. Umifenovir is another drug that has shown the virus-cell entry and fusion by inhibiting the clathrin-mediated endocytosis in human studies in the combination of lopinavir/ritonavir and ribavirin [63, 64]. Besides, other studies show that ouabain and bufalin (cardio-tonic steroids- available drugs) and chlorpromazine have this effect on MERS-CoV, so they could have the same effect on COVID-19 and need additional studies [25]. Studies show that chloroquine (CQ) is more effective than chlorpromazine for inhibition of clathrin-mediated endocytosis [3]. Umifenovir and CQ have been added to the National Health Commission of the People's Republic of China guideline for COVID -19 treatment [65].

\section{Lysosomotropic agents}

Through the membrane permeability, weak bases could leak to acidic organelles and become protonated in the low $\mathrm{pH}$, regarding their lipophilicity. After ionization, they catch up in the organelles (ion trapping) [66]. Agents with a viable function that accumulates in the Late Endosome/Lysosome vesicle with high concentration called "Lysosomotropism" [67]. Almost all of them shelter an amine group that makes them act as a weak base [66]. So they could diffuse into the endosome/lysosome vesicle, get trapped, and lead the protease inhibition by changing the $\mathrm{pH}$ and prevent the viral release for transcription [25,68]. Some drugs such as CQ and hydroxychloroquine(HCQ) [69] act as lysosomotropic agent so could trap the viral receptor $\mathrm{ACE}_{2}$ within perinuclear vacuoles, prevent the transcription of the viral genome and interrupt the virus life cycle. An open-label non-randomized clinical trial revealed that HCQ could significantly reduce or vanish the viral load in COVID-19 patients, its effect strengthen by azithromycin [70]. Another clinical study on 62 patients with COVID-19 infection in Renmin Hospital of Wuhan University was showed that HCQ could improve pneumonia significantly $(80.6 \%, 25$ of 31) compared with the control group $(54.8 \%, 17$ of 31) [71]. Also, some other molecules like ammonium chloride $(\mathrm{NH} 4 \mathrm{Cl})$ are known as lysosomotropic agents [72] (Table 2). They can enter in other acidic organelles such as Golgi vesicles, too. So, they also might prevent the virus life cycle in releasing the new virus particle outside the host cell [59] (replication step). The efficacy of HCQ and CQ against COVID-19 demonstrated in vitro and small, poorly controlled, or uncontrolled clinical studies [73]. Also, in vitro, studies show that HCQ is a more potent inhibitor of COVID19 compare to CQ [74]. Some reports are suggesting the effectiveness of dapagliflozin in the severe disease of COVID19 with inhibiting the cytosolic $\mathrm{pH}$ reduction and consequently reducing the viral load. [75]. There is no information regarding the exact mechanism but we can consider it in this stage of the virus life cycle. (NCT04350593) (NCT04393246).

\section{Direct endosomal/lysosomal protease inhibitors}

The antibiotic teicoplanin acts as a cathepsin L inhibitor in the late endosome so it could interrupt the COVID-19 life cycle by preventing the $\mathrm{S}$ protein cleavage and genome releasing to the host cell $[74,76]$. According to Zhou et al., telavancin and teicoplanin were shown this mechanism on SARS-CoV and MERS-CoV, previously [77]. Some other investigational drugs (such as E64d [25] and vitamins (such as folic acid [62] have shown the inhibitory activity for FURIN like proteases. Another study declared that E64d indirectly reduced COVID-19 RNA levels [78].

\section{Viral replication}

The viral genome, with several open reading frames (ORFs) [81], is translated into polyproteins by changing in the ribosomal frame [58, 82]. The first produced polyprotein gets an auto-proteolytic process leading to Papain-like (PL) and 3chymotrypsin-like (3CL) proteinases formation [58]. These viral proteinases have a crucial role in developing the 16 non-structural viral proteins (NSP 1 to 16) and, consequently, in the RNA replication-transcription complex [82]. PL proteinase plays a pathophysiological role in suppressing the innate immune response and inducing the cytokine expression by NSP3 activation [58]. The following steps of the replication-transcription complex occur in the viral-induced 
Table 2 The definition of molecules which are assumed to be effective in the disruption of Endocytosis Pathway

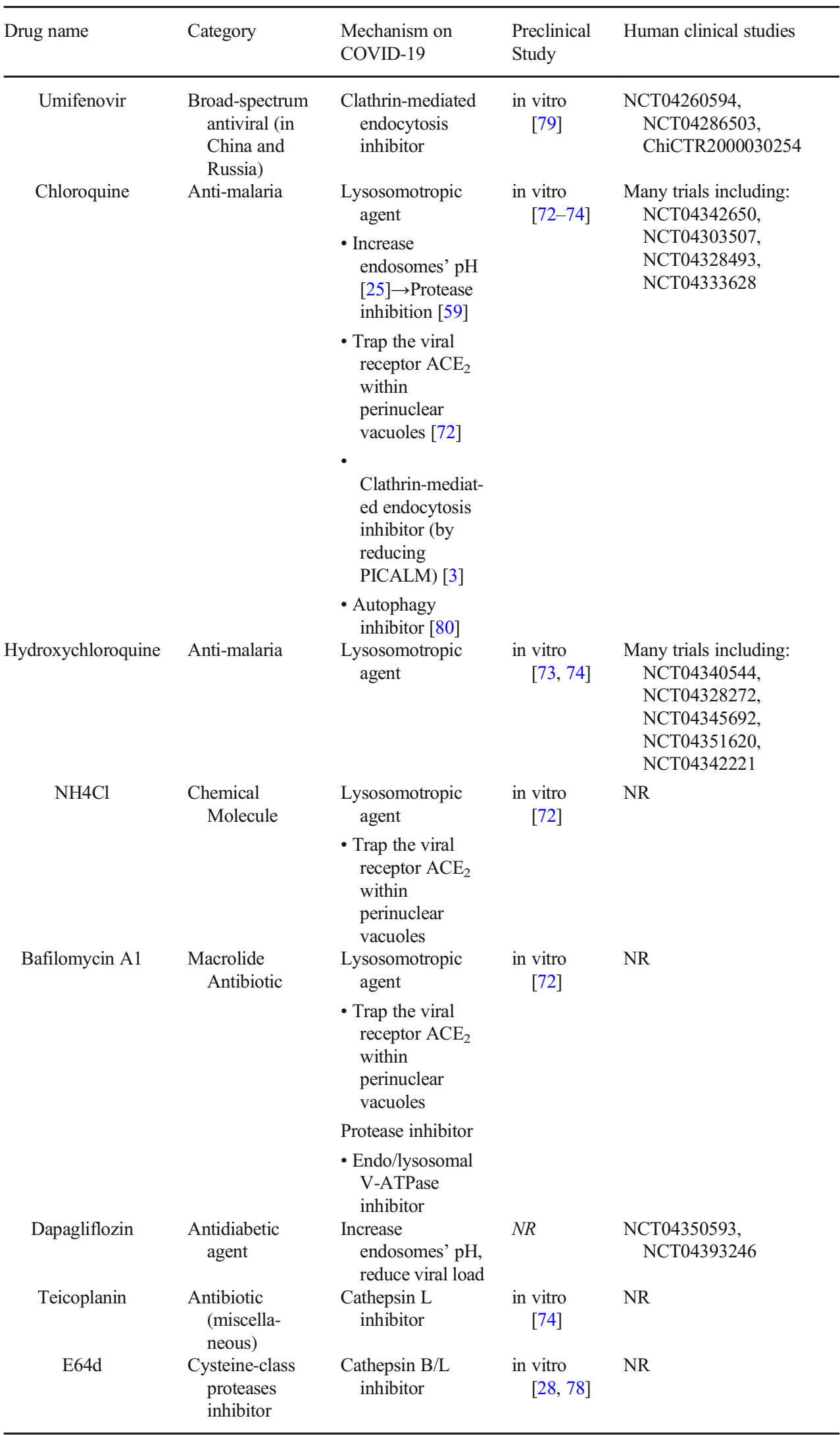

$N R$, Not Reported; $A C E_{2}$, Angiotensin-converting Enzyme-2; PICALM, Phosphatidylinositol Binding Clathrin Assembly Protein; V-ATPase inhibitor, Vacuolar-Adenosine Triphosphatase inhibitor 
DMVs [81]. 3CL proteinases promote the DMV creation by NSP4 activation. Generally, NSP 3, 4, and 6 contribute to DMV formation [58]. The DMV is the initial location for RNA replication [83]. The RNA virus replicates by a viral enzyme called RNA-dependent RNA polymerase (RdRp) or RNA-replicase, which locates in the NSP12 [84, 85] (Fig. 3).Some of ORFs are composed of the viral structural proteins encompass Spike, Membrane protein, Envelope protein, and Nucleocapsid protein [81]. FURIN-like enzymes form the bound between $S_{1}$ and $S_{2}$ subunit in the assembling stage in the Golgi $[60,86]$. The internal interferon releasing by the infected cells shows the inhibition of the FURIN-like enzyme to prevent the viral expression [61]. Finally, the vesicle containing COVID-19 viruses is exported outside the infected host cell after assembling in the Golgi system [87] (Fig. 3). The envelope (E) protein and membrane protein $(\mathrm{M})$ interact with each other in the budding compartment of the host cell. The $\mathrm{M}$ protein influence dominant cellular immunogenicity. Nucleoprotein (ORF9a) packages the positive-strand viral RNA genome into a helical ribonucleocapsid (RNP) during virion assembly via its interactions with the viral genome and membrane protein $\mathrm{M}$. Nucleoprotein plays a critical role in enhancing the efficacy of sub-genomic viral RNA transcription during viral replication [58].

There is a mechanism that is discussed, particularly on the red blood cells (RBC). The envelope and ORF8 protein could attach the porphyrin in the RBCs [88]. Concomitantly some other ORFs (orf1 ab, ORF3a, ORF10) could segregate the iron from heme and create porphyrin. So the active form of hemoglobin would be declined and affect the $\mathrm{O}_{2} / \mathrm{CO}_{2}$ transferring [89]. In conclusion, acute porphyria would occur. Also, the evidence of reducing hemoglobin levels exists in COVID-19 patients [90], and we can see the free iron chelator treatments (deferoxamine, NCT04333550, NCT04361032, NCT04389801) as a part of therapy for COVID-19 patients. CQ has been approved previously for the porphyria treatment [90].

We can categorize the potential treatments for viral replication into the main groups as below:

\section{Proteinase inhibitors}

We explained the crucial role of viral proteinases above. Regarding the importance of 3CL proteases in the COVID19 life cycle, we assume that the target of treatment is preventing NSPs production [58]. It is worth mentioning that the CL proteases of COVID-19, HCV (hepatitis C virus), and HIV (human immunodeficiency virus) reveal structural and functional sameness. The combination of danoprevir and ritonavir in the clinical trial has shown effective therapy against COVID-19 [90] (Table 3). However, there is also some controversy about them, as we see many cocktail treatments indicated that the available RNA virus protease inhibitors might have no sufficient efficacy alone in the treatment of COVID19 [92, 93] (NCT04276688, NCT04254874, ChiCTR2000029308). Reports show that lopinavir/ritonavir alone does not affect almost all patients with COVID-19. There is an in vitro study which illustrates the effectiveness of nelfinavir in inhibition of COVID-19 replication as an antiprotease [94]. Besides, diarylheptanoids (natural product) and cinanserin (serotonin receptor antagonist), which shows the PL and 3CL proteases activity in SARS-CoV, respectively [95], could be potential choices for COVID-19. However, it needs further studies.

\section{Direct RdRp inhibitors}

They could interrupt the RNA replication, so the new virion particles cannot infect the other host cells. Beclabuvir and sofosbuvir, as HCV RNA polymerase inhibitors, are under clinical trial (Table 3) and could be used as therapy [96]. In the in vitro studies, it is cleared that zinc and zinc pyrithione could inhibit the RdRp function of SARS-CoV and block the replication $[95,97]$. The clinical trials are mentioned in Table 3 .

\section{Nucleoside analogs}

They could cause premature termination of RNA replication and indirectly inhibit the RdRp activity, including remdesivir [93, 98, 99], ribavirin [93], and clevudine (Table 3). However, some findings indicated that the use of ribavirin plus lopinavir/ritonavir in comparison to ribavirin alone is more effective for preventing ARDS in COVID-19 patients [93]. There is a suggestion that illustrates remdesivir may be the best potential drug for the treatment of COVID-19 [92]. An in vitro study demonstrated that lopinavir but not ritonavir blocks the COVID-19 replication [100]. Effectiveness of Remdesivir was reported in an uncontrolled cohort study on $68 \%$ of patients (36 of 53) with severe COVID-19 [101]. In a randomized clinical study which was conducted on 237 patients (158 to Remdesivir group $=158$, placebo group $=79$ ); there was no difference in time to clinical improvement between groups [102]. However, introductory results from the 1059 patients indicated that the Remdesivir group $(n=538)$ had a median recovery time of 11 days in comparison with 15 days in the placebo group $(n=521)$ [103].

\section{Viral protein inhibitors}

Daclatasvir is an HCV non-structural protein inhibitor and vitamin B12 (methylcobalamin form) as an NSP12 blocker could be in COVID-19 treatment consideration by interrupting the virus life cycle, also patients receiving the combination of sofosbuvir and daclatasvir showed a shorter hospital stay [84]. Regarding the role of COVID-19 on RBCs, 
Table 3 The definition of molecules which are assumed to be effective in the disruption of the COVID-19 Replication

\begin{tabular}{|c|c|c|c|c|}
\hline Drug name & Category & Mechanism on COVID-19 & Preclinical studies & Human clinical studies \\
\hline Danoprevir & Anti HCV(in China) & $\begin{array}{l}\text { Chymotrypsin-like protease } \\
\text { inhibitor [91] }\end{array}$ & in silico [109] & NCT04291729, NCT04345276 \\
\hline Ritonavir & Anti HIV & $\begin{array}{l}\text { Chymotrypsin-like protease } \\
\text { inhibitor [91] }\end{array}$ & $\begin{array}{l}\text { in silico, in vitro, } \\
\text { animal models } \\
{[109]}\end{array}$ & $\begin{array}{l}\text { NCT04291729, } \\
\text { +Lopinavir: NCT04307693, NCT04330690, } \\
\text { NCT04321174, NCT04276688, } \\
\text { NCT04321993, NCT04315948 }\end{array}$ \\
\hline Lopinavir & Anti HIV & Protease inhibitor & $\begin{array}{l}\text { in silico, in vitro, } \\
\text { animal models } \\
{[100,109]}\end{array}$ & NCT04307693 \\
\hline Remdesivir & $\begin{array}{l}\text { Nucleotide analog } \\
\quad \text { (investigational) }\end{array}$ & $\begin{array}{l}\text { Rd Rp inhibitor, premature } \\
\text { termination of RNA replication }\end{array}$ & in vitro [99] & $\begin{array}{l}\text { NCT04292899 } \\
\text { NCT04292730 } \\
\text { NCT04280705 } \\
\text { NCT04321616 } \\
\text { NCT04302766 }\end{array}$ \\
\hline Clevudine & $\begin{array}{l}\text { Anti HBV (in South } \\
\text { Korea and the } \\
\text { Philippines). }\end{array}$ & $\begin{array}{l}\text { Rd Rp inhibitor, premature } \\
\text { termination of RNA replication }\end{array}$ & NR & NCT04347915 \\
\hline Beclabuvir & Anti HCV & Rd Rp inhibitor [96] & in vitro [91] & NR \\
\hline Sofosbuvir & Anti HCV & Rd Rp inhibitor & in silico $[110]$ & IRCT20200128046294N2 \\
\hline Daclatasvir & Anti HCV & NSP inhibitor & in silico [109] & IRCT20200128046294N2 \\
\hline Zinc & Microelement & Rd Rp inhibitor & NR & $\begin{array}{l}\text { NCT04335084, NCT04351490, } \\
\text { NCT04342728, NCT04326725, } \\
\text { NCT04334512 }\end{array}$ \\
\hline Ribavirin & $\begin{array}{l}\text { Anti HCV } \\
\text { (Nucleotide } \\
\text { analog) }\end{array}$ & $\begin{array}{l}\text { RdRp inhibitor, premature } \\
\text { termination of RNA replication }\end{array}$ & in silico [110] & NCT04276688, NCT04293887, NCT04306497 \\
\hline Methylcobalamin & Vitamin B12 & $\begin{array}{l}\text { NSP12 blocker, RdRp inhibitor } \\
\text { indirectly }\end{array}$ & in silico [84] & NCT04407572 \\
\hline Nelfinavir & Anti-HIV & Protease inhibitor & in vitro [111] & NR \\
\hline Chloroquine & Anti-malaria & $\begin{array}{c}\text { inhibit orflab, ORF3a, ORF10, } \\
\text { ORF8 and envelope protein }\end{array}$ & in vitro [79] & (mentioned Table 2) \\
\hline Hydroxychloroquine & Anti-malaria & Reduce replication & in vitro [79] & (mentioned Table 2) \\
\hline Favipiravir & $\begin{array}{l}\text { Anti-influenza (in } \\
\text { Japan) }\end{array}$ & $\begin{array}{l}\text { mRNA translation interruption } \\
\text { [104], Envelope, and ORF7a } \\
\text { protein inhibitor }\end{array}$ & in silico [109] & $\begin{array}{l}\text { 61.21\% recovery after } 7 \text { days on COVID-19 } \\
\quad \text { (ChiCTR2000030254) [112] } \\
\text { NCT04345419, NCT04349241 }\end{array}$ \\
\hline Ivermectin & Anthelmintic & Nucleocapsid protein inhibitor & in vitro [107] & $\begin{array}{l}\text { NCT04343092, NCT04351347, } \\
\text { NCT04345419, }\end{array}$ \\
\hline
\end{tabular}

$N R$, Not Reported; $H C V$, Hepatitis C Virus; $H I V$, Human Immunodeficiency Virus; RdRp, RNA-Dependent RNA Polymerase; $H B V$, Hepatitis B Virus; $N S P$,non-structural protein; $O R F$, Open Reading Frame

studies show that CQ could inhibit orflab, ORF3a, ORF10, ORF8, and envelope protein to affect the RBCs and effectively alleviate the symptoms of ARDS [89]. Favipiravir could block the envelope and ORF7a protein attaching the porphyrin, preventing the entrance to the host cells, and catching free porphyrins [89]. Also, it could reduce the viral load by interrupting the mRNA translation [104]. It is claimed that ORF-3a are codes for an ion-permeable channel in the SARS-CoV's infected cells, which could be related to the virus release [105]. So emodin or kaempferol derivativesjuglanin could potentially prevent the viral release from the infected cells by inhibition of the ion channel [106]. Besides, ivermectin could prevent SARS-CoV nucleocapsid protein and interrupt the release of the viral genome into the host cell [107]. It also has shown efficacy on COVID-19 in vivo [108]. There is some evidence regarding the alleviation of ARDS in the severe cases of COVID-19 [108]. Table 3 shows the summary of drugs that could affect the COVID-19.

\section{Inflammatory reactions}

Besides the role of the virus life cycle in the pathophysiology of COVID-19, there is some strong evidence about the patient's inflammatory reaction, which mainly causes the comorbidity and mortality in severe conditions [113], including lung, liver, heart, and kidney failure [114]. Interferons (IFNs), 
a group of cytokines, have an important impact on the immune system against pathogens like CoVs [115]. There are various mechanisms for suppressing the immune system by $\mathrm{CoVs}$ [116]. First: CoVs could prevent the internal type-I IFN rapid production (such as IFN $\alpha$ and $\beta$ ), which could be related to severe symptoms and death $[115,116]$. Second: STAT1, as the JAK-STAT (Janus kinase/signal transducers and activators of transcription) component, is blocked by CoVs, which lead to the prevention of type-I IFN signaling [115, 116]. Immune exhaustion is the third defensive mechanism of COVID-19, thereby exaggerates and prolongs IFN-1 production by plasmacytoid dendritic cells (pDCs) [116]. In conclusion, the hyperactive immune cells, including neutrophils, monocytes, the "cytokine storm" and IFN-1 induced T cell apoptosis to emerge in infected organs, especially the lung [116]. Besides, cytokines released from activated $\mathrm{T}$ helper (Th) cells contribute to autoimmune disorders [117]. The $\mathrm{Th}_{1}$ cytokines encompass IL-2, IFN $\gamma$, and TNF- $\alpha$ (tumor necrosis factor-alpha) more involved for cellular immunity [117]. The other group, the $\mathrm{Th}_{2}$ cytokines, including IL-4, IL-5, IL-6, IL-10, IL-11, and IL-13, have a role in B cell mediated humoral immunity $[117,118]$.

Data from plasma samples of patients admitted to ICU indicate various cytokines levels that are higher than usual, which are signs of "Cytokine Storm. These cytokines include: IFN- $\gamma$ [113], IL-1 $\beta$, IL-2, IL-6, IL-7, IL-8, IL-9, IL-10, IL-17, G-CSF (granulocyte-colony stimulating factor), GM-CSF (granulocyte-macrophage-CSF), $\mathrm{IP}_{10}$ (interferon- $\gamma$-inducible protein), $\mathrm{MCP}_{1}$ (monocyte chemoattractant protein), $\mathrm{MIP}_{1 \alpha}$ (macrophage inflammatory protein 1 alpha), $\mathrm{MIP}_{1 \beta}$, and TNF- $\alpha[114,119,120]$. Another common symptom in severe cases or mortalities are lymphopenias [121]. Some studies suggested that the IL-6 plasma level could aim to forecast lung complications in patients [118]. Some other worth mentioning feature is the $\mathrm{CD}_{4}$ (cluster of differentiation-4) and $\mathrm{CD}_{8} \mathrm{~T}$ cells reduction in number but with higher immune activities. Additionally, the concentrated pro-inflammatory cytokines, including IL-17 in $\mathrm{CD}_{4}$ and cytotoxic granules in $\mathrm{CD}_{8} \mathrm{~T}$ cells, exhibit the pathologic inflammatory reactions of $\mathrm{T}$ cells in COVID-19 patients. So it is demonstrated that the rise in $\mathrm{Th}_{17}$ cells and the $\mathrm{CD}_{8}$ cytotoxicity could contribute to severe damages in the infected organs [122]. $\mathrm{Th}_{17}$ cells are $\mathrm{CD}_{4}$ positive $\mathrm{T}$ cells that release the IL-22, IL-6, TNF- $\alpha$, and exclusively IL-17 [123]. They can be differentiated easily into various types of Th cells to either enhance the immune system for body protection against microorganisms or regulate immunogenicity reactions with IL-10. However, studies show that $\mathrm{Th}_{17}$ cells have a crucial role in autoimmune disorders [123, 124]. Generally, studies assume that the reduction of IL-6, IL8 , IL-17, TNF- $\alpha$ could prevent inflammatory-induced damages $[125,126]$. Another worth mentioning topic is the role of oxidative stress in CoVs pathogenicity. Reactive oxygen species (ROS) are a series of by-products derived from molecular oxygen $\left(\mathrm{O}_{2}\right)$ created in respiring cells during mitochondrial oxidative phosphorylation. Besides, ROS can come from extra-cellular origins such as smocking, metals, drugs, xenobiotics, radiation, and infection [127]. ROS produces continuously during viral infections. It could be effective for attacking the virus and also be harmful to normal cellular functions. When the balance is interrupted, the extra amount of ROS could lead to oxidative [128]. CoVs proteins affect mitochondrial integrity, proteasome function, and cause the generation of ROS [129]. It could be lead to the mitochondrial malfunction and aggregation of both host cell and viral proteins by affecting the proteasome (hamper cellular functions). Mortality of Patients by SARS-CoV and COVID-19 is related to inflammatory disorders. Patients with smoking, diabetes, cancer, and cardiovascular diseases almost have reducedactivity proteasome. Besides, proteasome activity could directly diminish by SARS-CoV proteins [129]. Smoking is responsible for proteasome inhibitory in pulmonary epithelial cells. Also, inflammatory disorders and obesity may increase cellular stress. Therefore, they could lead the infected cells incapable of getting rid of protein aggregates. Also, some believe that virally-induced ROS could trigger the STAT/IL6 axis, cytokine formation, and infiltration of immune cells in the lung [129]. Some animal models of influenza and coxsackie viruses illustrated the changing in virus genome (the normal or mild pathogenic alter to the aggressive one) in host cells suffering the oxidative stress with ambiguous molecular mechanisms [128].

\section{Thromboembolism mechanism in COVID-19}

Another finding of COVID-19 pathophysiology is thromboembolism in bronchial arterioles [130] which could be defined by inflammatory mechanism lead to an interruption in procoagulant-anticoagulant balance and initiating the micro thrombosis, disseminated intravascular coagulation, and organ failure. The finding would be confirmed by the higher level of d-dimer in poor prognosis severe COVID-19 pneumonia and disseminated intravascular coagulation in expired patients [131]. So low molecular weight heparin (LMWH) for venous thromboembolism prevention or treatment in hospitalized patients with significantly high levels of d-dimer is recommended. Also, the anti-inflammatory effect of LMWH might play a beneficial role in COVID-19 management. Besides, the administration of antithrombin and anti-factor Xa direct oral anticoagulants as the well-established drugs in the prevention and treatment of venous thromboembolism might be useful [131]. Some findings suggested that the COVID-19 could suppress the production of pulmonary surfactant via binding the $\mathrm{ACE}_{2}$ receptors on $\mathrm{AEC}_{\mathrm{II}}$. It might be responsible for ARDS presentation in severe cases. Therefore, the administration of pulmonary surfactants or stimulators of surfactant production would be useful as either treatment or 
prevention [132]. Using anti-inflammatory treatments could prone the patient with secondary infections [133]. Based on almost all anti-inflammatory drug monographs, it is a noticeable warning about concomitant infection since they are suppressive agents for the innate immune system, too. It must be under consideration for use in the COVID-19 treatment protocol. However, we can categorize the possible drug which would affect the Inflammatory Reactions as below (Table 4).

\section{Viral defense blockers}

As it is clearly defined, the COVID-19 applied three main defensive mechanisms against the host immune system. Studies show that the percentage of $\mathrm{CD}_{8} \mathrm{~T}$ cells with PD-1 (programmed cell death-1) is increased in COVID-19 ICU patients significantly comparing to both non-ICU and healthy individuals. The increment of PD-1 in T cells indicated T cell exhaustion [134]. Exhaustion of T cells indicated immunosuppression after the prolongation of some diseases like infection $[134,135]$ and might overcome by utilization of investigational PD-1 inhibitors (camrelizumab, Table 4) [136], especially at the end stage of the disease. Besides, one antiprotozoal drug (nitazoxanide) has exhibited the potential anti-viral activity, particularly on COVID-19 in vitro. The efficacy mechanism is assumed by blocking the COVID-19 defensive reaction to the internal IFNs [99], and it has been studying for hospitalized patients with moderate COVID-19 (Table 4).

\section{Direct interleukin antagonists}

According to the imperative role of interleukins information of cytokine storm in COVID-19 patients, we assume that they might alleviate the immune reaction and save the organ damage. Tocilizumab and sarilumab are IL-6 blockers, anakinra is IL-1 blocker, and dupilumab is IL-4, IL-13 antagonist is now under clinical trial for COVID-19 [137, 138]. This report shows that dupilumab could be beneficial for cytokine storm in older patients [138]. The latest update of the CDC on June 11, 2020, shows that earlier use of Tocilizumab decreases mortality and improves oxygenation. This report although shows that Anakinra improves respiratory distress but was stopped because of complications.

\section{Pro-inflammatory inhibitors}

Some drugs could interrupt the production of proinflammatory cytokines that would contribute to preventing the cytokine storm, such as CQ, HCQ [59, 69, 139], macrolide antibiotics like azithromycin (in vitro) [126] and corticosteroids like methylprednisolone [140]. A single centered, retrospective, observational study on 60 COVID-19 adult patients in Baqiyatallah Hospital, Tehran, Iran was showed that the short-term use of low-dose prednisolone in combination with azithromycin, naproxen, and lopinavir/ritonavir, have a beneficial effect in oxygen saturation, serum level of c-reactive protein and shortening the average length hospitalization in comparison with meropenem, levofloxacin, vancomycin, HCQ, and oseltamivir [141]. However, the concern of QTc prolongation arrived from a study on 84 patients who were receiving HCQ and azithromycin for COVID-19 treatment [142].

\section{Corticosteroids}

As mentioned above cytokine storm lead to severe tissue damage especially organs rich in $\mathrm{ACE}_{2}$ receptors like the lung. This damage causes ARDS that is the main cause of death. Corticosteroids can diminish this damage by reducing inflammatory cytokines like IL-1 and IL-6. They also increase the production of IL-10, an anti-inflammatory mediator. It is claimed that using methylprednisolone could reduce the mortality rate especially in severe cases of ARDS [143]. Although there was some controversy against using corticosteroids like dexamethasone in COVID-19 treatment [144], The National Institutes of Health on June 25, 2020, has recommended the administration of dexamethasone only in patients need either mechanical ventilation or supplemental oxygen [145].

\section{Other pro-inflammatory inhibitors}

Recombinant human $\mathrm{ACE}_{2}$, which has studied in ARDS patients, indicated the reduction in the plasma level of inflammatory proteins like IL- 6 and could be categorized as well [33]. Also, the cytokine storm theoretically could be treated by a single S1P (sphingosine 1 phosphate) agonist molecule [146]. Fingolimod, as an S1P, inhibits IL-6, skew IFN responses, and decreases pulmonary fibrosis [147]. Also, some investigational agents like S1P analog (FTY720) and all-trans retinoic acid or other analogs could block IL-17 and prevent the $\mathrm{Th}_{2}$ differentiation [148]. Since etanercept was showed as a TNF blocker and IL-17/IL-22 modulator in psoriatic patients [124], it may be helpful for cytokine storm inhibition. Also, some drugs, including colchicine, thalidomide, emapalumab, atazanavir. and IVIG, are under clinical trial for COVID-19 with their previous pro-inflammatory inhibitory mechanism (Table 4).

\section{JAK-STAT signaling inhibitors}

Disruption in JAK-STAT signaling leads to a variety of immune-related diseases and cancers [149]. Patients with COVID-19 usually exhibit high levels of cytokines in the plasma so that the JAK-STAT signaling inhibitors might be useful in the treatment. Baricitinib, fedratinib, and ruxolitinib are JAK inhibitors and dominant anti-inflammatory drugs [113]. Baricitinib is on a clinical trial for COVID-19 besides 
Table 4 The definition of molecules which are assumed to be effective in the treatment of COVID-19 by affecting the inflammatory reactions

\begin{tabular}{|c|c|c|c|}
\hline Drug name & Category & Mechanism on COVID-19 & Human clinical studies \\
\hline Camrelizumab & $\begin{array}{l}\text { Humanized monoclonal } \\
\text { PD-1 antibody } \\
\text { (oncology-investigational) }\end{array}$ & Viral Defense Blockers & $\begin{array}{l}\text { ChiCTR2000029806 } \\
\text { NCT04268537 }\end{array}$ \\
\hline Nitazoxanide & Anti-protozoal & Viral Defense Blockers & $\begin{array}{l}\text { NCT04348409, NCT04343248, NCT04351347, } \\
\text { NCT04341493, NCT04345419 }\end{array}$ \\
\hline Tocilizumab & Antirheumatic & $\begin{array}{l}\text { IL-6 receptor antagonist, licensed } \\
\text { for cytokine release syndrome } \\
\text { [137] }\end{array}$ & $\begin{array}{l}\text { ChiCTR2000029765, NCT04317092, NCT02097524, } \\
\text { NCT04306705, NCT04332094, NCT04332913, } \\
\text { NCT04339712, NCT04315480 }\end{array}$ \\
\hline Sarilumab & Antirheumatic & IL-6 receptor antagonist & $\begin{array}{l}\text { NCT04315298, NCT04341870, NCT04327388, } \\
\text { NCT04321993, NCT04345289 }\end{array}$ \\
\hline Dupilumab & Anti-Asthmatic & $\begin{array}{l}\text { IL-4 and IL-13 receptor antagonist } \\
\text { [138] }\end{array}$ & NCT04324866 \\
\hline Anakinra & Antirheumatic & IL-1 blocker & $\begin{array}{l}\text { NCT04324021, NCT04339712, NCT04341584, } \\
\text { NCT04330638, NCT02735707 }\end{array}$ \\
\hline Emapalumab & IFN $\gamma$ Monoclonal Antibody & Pro-inflammatory inhibitor & NCT04324021 \\
\hline $\begin{array}{l}\text { Recombinant human } \\
\mathrm{ACE}_{2}\end{array}$ & Soluble $\mathrm{ACE}_{2}$ & Pro-inflammatory inhibitor & NCT04287686, NCT04335136 \\
\hline Fingolimod & $\mathrm{S} 1 \mathrm{P}$ receptor Modulator & Pro-inflammatory inhibitor & NCT04280588 \\
\hline Methylprednisolone & Corticosteroids & Pro-inflammatory inhibitor & $\begin{array}{l}\text { Many trials including: NCT04263402, NCT04323592, } \\
\text { NCT04244591, NCT04341038, NCT04345445, } \\
\text { NCT04263402 }\end{array}$ \\
\hline Azithromycin & Macrolide antibiotics & Pro-inflammatory inhibitor & $\begin{array}{l}\text { NCT04321278, NCT04329832, NCT04336332, } \\
\text { NCT04345419, NCT04332107, NCT04334382 }\end{array}$ \\
\hline Infliximab & Antirheumatic & $\begin{array}{l}\text { Pro-inflammatory inhibitor (TNF } \alpha \\
\text { blocker) }\end{array}$ & NCT04425538, NCT04344249 \\
\hline Baricitinib & Antirheumatic & JAK inhibitor & $\begin{array}{l}\text { NCT04320277, NCT04346147, NCT04321993, } \\
\text { NCT04345289 }\end{array}$ \\
\hline Ruxolitinib & Antineoplastic Agent & JAK inhibitor & $\begin{array}{l}\text { NCT04348071, NCT04334044, NCT04338958, } \\
\text { NCT04331665, NCT04337359 }\end{array}$ \\
\hline Tofacitinib & Antirheumatic & JAK inhibitor & $\begin{array}{l}\text { NCT04412252, NCT04415151, NCT04390061, } \\
\text { NCT04332042 }\end{array}$ \\
\hline Atazanavir & Anti HIV & $\begin{array}{l}\text { Pro-inflammatory and viral } \\
\text { replication inhibitor [156] }\end{array}$ & NCT04452565, NCT04459286 \\
\hline IVIG & Immunoglobulin & $\begin{array}{l}\text { Anti-inflammatory, } \\
\text { immunosuppressive [32] }\end{array}$ & NCT04350580, NCT04261426 \\
\hline Chloroquine & Anti-malaria & $\begin{array}{l}\text { Blocking the pro-inflammatory } \\
\text { genes transcription }[59,157]\end{array}$ & (mentioned in Table 2) \\
\hline Hydroxychloroquine & Anti-malaria & $\begin{array}{l}\text { Blocking the transcription of the } \\
\text { pro-inflammatory gene [59] }\end{array}$ & (mentioned in Table 2) \\
\hline Colchicine & Antigout & $\begin{array}{l}\text { Reducing the release of IL- } 1 \mathrm{~b} \text { and } \\
\text { an array of other interleukins, } \\
\text { including IL-6 }\end{array}$ & $\begin{array}{l}\text { NCT04322565, NCT04326790, NCT04328480, } \\
\text { NCT04322682, NCT04350320 }\end{array}$ \\
\hline Thalidomide & Angiogenesis inhibitor & $\begin{array}{l}\text { Anti-inflammatory, anti-fibrotic, } \\
\text { and immune regulatory effects. }\end{array}$ & NCT04273529, NCT04273581 \\
\hline $\mathrm{IFN} \alpha 1 \mathrm{~b}$ & Interferon & $\begin{array}{l}\text { Antiviral and anti-inflammatory } \\
\text { activity }\end{array}$ & NCT04293887, NCT04320238 \\
\hline $\begin{array}{l}\text { Peginterferon } \\
\text { Lambada-1a }\end{array}$ & Interferon & $\begin{array}{l}\text { Antiviral and anti-inflammatory } \\
\text { activity }\end{array}$ & NCT04344600 \\
\hline $\mathrm{IFN} \alpha 2 \mathrm{~b}$ & Interferon & $\begin{array}{l}\text { Antiviral and anti-inflammatory } \\
\text { activity }\end{array}$ & NCT04254874, ChiCTR2000029308 \\
\hline IFN $\beta 1$ & Interferon & $\begin{array}{l}\mathrm{CD}_{73} \text { induction, the release of the } \\
\text { anti-inflammatory agents }\end{array}$ & NCT04343768 \\
\hline Vitamin $\mathrm{C}$ & Water-soluble vitamin & Oxidative stress inhibitor & $\begin{array}{l}\text { NCT04347889, NCT04328961, NCT04323514, } \\
\text { NCT04323228, NCT04335084, NCT04342728 }\end{array}$ \\
\hline Vitamin D & Fat-soluble vitamin & Oxidative stress inhibitor & NCT04335084, NCT04351490 \\
\hline Bromhexine & Mucolytic Agent & Surfactant replacement & $\begin{array}{l}\text { NCT04405999, NCT04273763, NCT04355026, } \\
\text { NCT04424134 }\end{array}$ \\
\hline Beractant & Pulmonary surfactant & Surfactant replacement & IRCT20091201002804N12 \\
\hline
\end{tabular}


Table 4 (continued)

\begin{tabular}{llll}
\hline Drug name & Category & Mechanism on COVID-19 & Human clinical studies \\
\hline $\begin{array}{l}\text { Bovine lipid extract } \\
\text { surfactant }\end{array}$ & Pulmonary surfactant & Surfactant replacement & NCT04362059 \\
\begin{tabular}{l} 
Poractant alpha \\
\hline
\end{tabular} & Pulmonary surfactant & Surfactant replacement & NCT04384731 \\
\hline
\end{tabular}

the antiviral treatment, which is conducted for the assessment of ICU admission reduction (Table 4). Tofacitinib, as a JAK inhibitor, has been shown to block interferon- $\alpha$ production in vitro [133],

\section{Interferons}

Due to the antiviral and anti-inflammatory activity of IFNs, some studies are going on. In one clinical study, the combination of inhalable IFN $\alpha$ and lopinavir/ ritonavir are recommended as antiviral therapy for COVID-19 (NCT04251871) [93]. Some other studies evaluated, IFN $\alpha 2 b$, in combination with lopinavir/ ritonavir and ribavirin (NCT04254874, 2/5/20, and ChiCTR2000029308, 1/23/20), but there is no published result regarding them. Also, the treatment effect of IFN $\alpha 1 \mathrm{~b}$ is evaluated in another study in Wuhan (NCT04293887). The preventive effect of nasal IFN $\alpha$ (NCT04320238) and peginterferon lambada-1a (NCT04344600) on COVID-19 infection in the medical staff has also carried out. The results of a prospective single-arm clinical trial on 20 patients with severe COVID-19 disease revealed that the use of subcutaneous IFN $\beta 1 \mathrm{a}$ in combination with HCQ and lopinavir/ritonavir would be beneficial in the management of COVID-19 [150]. Besides, a multicenter, prospective, open-label, randomized, phase 2 trial on 127 patients in Hong Kong Hospital suggested that antiviral therapy with IFN $\beta 1 \mathrm{a}$, lopinavir-ritonavir, and ribavirin were safe and superior to lopinavir-ritonavir alone in shortening virus shedding, alleviating symptoms and facilitating discharge of patients with mild to moderate COVID-19 (NCT04276688) [151]. when given within 7 days of symptom onset, is effective in suppressing the shedding of SARS-CoV-2, not just in a nasopharyngeal swab, but in all clinical specimens, compared with lopinavir-ritonavir alone. They hypothesized that a triple combination of modest antiviral drugs might rapidly suppress the high initial viral load, improve the clinical parameters, and reduce the risk of health-care workers by reducing the duration and quantity of virus shedding from these treated patients [151]. Eight of ten patients also had real-time RT-PCR-positive rectal swabs, suggesting potential fecal viral excretion, suggesting that the gastrointestinal tract may shed virus and fecal-oral transmission may be possible [152]. All patients received antiviral therapy with $\alpha$-interferon oral spray initiated from admission (8000 U, two sprays, three times a day). Viral RNA measurements suggest that viral shedding from the digestive system might be greater and last longer than that from the respiratory tract [152].

Also, it is assumed that IFN $\beta 1$ has a vital effect on the protection of pulmonary cells and the treatment of CoVs. IFN $\beta 1$ induced $C_{73}$ in endothelial cells that lead to the release of the anti-inflammatory agents and keep the barrier capacity of endothelial cells. Therefore, a decrease in vascular leakage in ARDS patients treated with IFN $\beta 1 \mathrm{a}$ might account for the defined mechanism. However, the death reduction in ARDS patients has not satisfied yet with clinical evidence. Generally, IFN $\beta$ has more efficacy compare to IFN $\alpha$ in the suppression of CoVs [153]. The comparison of IFN $\beta 1 \mathrm{a}$ and IFN $\beta 1 \mathrm{~b}$ is ongoing in a clinical study (NCT04343768).

\section{Oxidative stress inhibitors}

As almost all nutrition have an essential role in preventing oxidative stress, it seems that they could be effective in COVID-19 treatment. Vitamin E is an antioxidant and selenium via assisting a group of enzymes, which could contribute to preventing the ROS generation and cell damages [95]. Also, selenium deficiency leads the host cells to oxidative stress [128]. Besides, it seems that inhibition of neutrophil infiltration to the pulmonary cells by vitamin $B_{3}$ treatment, which is observed in patients with ventilator-induced lung damage, might be related to its antioxidant activity in addition to the known antiinflammatory effects [95]. Also, studies show that the people infected by the virus might have vitamin D (a membrane antioxidant) deficiency [95]. Although the Iron insufficiency could suppress the immune system, the excess amount of it could induce oxidative stress [95]. Some studies suggested that using melatonin with the anti-inflammatory, anti-oxidant, and immune system modulatory effects could come in handy with COVID19 patients [154].

Since the possibility of lowering the incidence of lower respiratory tract infection in particular circumstances had been reported previously [95], it seems that a moderated 
dose of vitamin $\mathrm{C}$ might be preventing COVID-19 [155]. Among all nutrition's, intravenous vitamin $\mathrm{C}$ effect as a potent antioxidant for viral treatment is being assessed in clinical trials on patients with COVID-19 (Table 4).

\section{Surfactant replacement}

As discussed, some possible drugs could prevent ARDS. Ambroxol and bromhexine could induce the production of pulmonary surfactant by affecting the $\mathrm{AEC}_{\mathrm{II}}$. Also, it is claimed that bromhexine inhibits TMPRSS2 and inhibits viral entry [132]. Besides, the use of pulmonary surfactant might be effective in the treatment of ARDS due to the COVID-19 as there are some ongoing clinical trials (Table 4).

\section{Discussion}

There are several types of research on the COVID-19 which have been conducting. It seems that prevailing over the pandemic would be achieved only by mastering over the virus pathophysiology. We tried to categorize the massive amount of available information into two main parts, the "virus life cycle" and the "Inflammatory Reactions" for useful interpretation. According to the explained information, besides attempts for discovering a novel pharmaceutical agent, we would find the effective ones more quickly through the present drugs. As a conclusion for the present review, we suggested that the treatment protocol would be occasional based on the stage of the infection and the patient situation. It is worth mentioning that the prescription of off-label medicine in clinical practice may provide the opportunity for COVID19 treatment; although there are some ethical issues to be regarded [158].

\section{Conclusion}

Presently there is no effective drug for COVID-19, so based on the affected organ and severity of the disease, the cocktail of medicines, which mainly consists, antivirals and immunomodulators can affect almost all mentioned stages of COVID19 disease, might be vital for patients.

\section{Compliance with ethical standards}

Conflict of interest The authors have no conflict of interest to be declared.

\footnotetext{
Abbreviation CoVs, Coronaviruses; SARS, Severe acute respiratory syndrome; MERS, Middle East respiratory syndrome; $\mathrm{ACE}_{2}$, Angiotensin-converting enzyme-2; CME, Clathrin-mediated endocytosis; $\mathrm{AEC}_{\mathrm{II}}$, Alveolar epithelial type II cells; IVIG, Intravenous immunoglobulin; ECMO, Extracorporeal membrane oxygenation; RAAS, Renin
}

angiotensin aldosterone system; TMPRSS2, Transmembrane protease serine 2; DMV, Double Membrane Vesicle; PICALM, Phosphatidylinositol binding clathrin assembly protein; HIV, Human immunodeficiency virus; HCV, Hepatitis $\mathrm{C}$ virus; RCT, Randomized clinical trial; TNF- $\alpha$, Tumor necrosis factor-alpha; G-CSF, Granulocyte-colony stimulating factor; GM-CSF, Granulocyte-macrophage colonystimulating factor; $\mathrm{IP}_{10}$, Interferon- $\gamma$-inducible protein; $\mathrm{MCP}_{1}$, Monocyte chemoattractant protein; $\mathrm{MIP}_{1 \alpha}$, Macrophage inflammatory protein 1 alpha; $\mathrm{MIP}_{1 \mathrm{~B}}$, Macrophage inflammatory protein 1 beta; $\mathrm{S} 1 \mathrm{P}$, Sphingosine 1 phosphate; PD-1, Programmed cell death 1; JAK-STAT, The Janus kinase/signal transducers and activators of transcription; CD, Cluster of differentiation; NSP, Non structural protein; ARDS, Acute respiratory distress syndrome

\section{Glossary}

$\mathrm{ACE}_{2}$ receptors: The typical type I integral membrane protein which the basis domain placed extracellularly [159].

Clathrin-mediated The primary mechanism of transferring endocytosis: Human- $\mathrm{ACE}_{2}$ transgenic mice: cargo molecules into the cell [160]. Transgenic mice with overexpression of the human receptor $\mathrm{ACE}_{2}$ for investigational purposes [161].

Fulminant myocarditis: Acute heart failure and myocardium inflammation are due to inflammatory events mostly triggered by viral infections [162].

Autophagy: The process of gathering the defected organelles and aged proteins in a DMV to link with lysosomes for recycling [80].

Proteasome: $\quad$ A large protein complex that contributes to the degradation of intracellular energy-dependent proteins [163].

Acute porphyria: The life-threatening attack occur when there is an interruption (including inherited, drug-induced, hormonal changes) during the heme biosynthetic pathway [164].

Cellular immunity: The system is in charge of detecting the body cells from the stranger by recognition and elimination of intracellular pathogens and infected cells with microorganisms $[165,166]$.

Humoral immunity: The response, which is mediated by antibodies, supports the body against extracellular pathogens and toxins $[165$, 166].

Cytokines: $\quad$ The small proteins including proinflammatory (IL-1 $\beta$, IL-6, TNF- $\alpha$ ) and anti-inflammatory cytokines with a crucial role in interaction and communication among cells, which are mainly released by helper $\mathrm{T}$ cells (Th) and macrophages [167]. 
JAK-STAT

signaling:

Oxidative stress:
The major chain of events with a crucial role in the regulation of division, differentiation, and death of mammal cells [149].

The proteins, nucleic acids, and cell membranes damaging events caused by exposure to reactive oxygen intermediates, such as superoxide anion $\left(\mathrm{O}^{-}\right)$, hydrogen peroxide $\left(\mathrm{H}_{2} \mathrm{O}_{2}\right)$, and hydroxyl radical (HO.) [168].

\section{References}

1. Leth-Larsen R, Zhong F, Chow V, Holmskov U, Lu J. The SARS coronavirus spike glycoprotein is selectively recognized by lung surfactant protein D and activates macrophages. Immunobiology. 2007;212(3):201-11.

2. Bernheim A, Mei X, Huang M, Yang Y, Fayad Z, Zhang N, et al. Chest CT findings in Coronavirus Disease-19 (COVID-19): relationship to duration of infection. Radiology. 2020;200463.

3. $\mathrm{Hu} \mathrm{T}$, Frieman $\mathrm{M}$, Wolfram J. Insights from nanomedicine into chloroquine efficacy against COVID-19. Nat Nanotechnol. 2020;15:247-9.

4. H. de Wilde A, al e. Host factors in coronavirus replication. inroles of host gene and non-coding RNA expression in virus infection. 2017; Springer, Cham.:1-42.

5. Funk C, Wang J, Ito Y, Travanty E, Voelker D, Holmes K, et al. Infection of human alveolar macrophages by human coronavirus strain 229E. The Journal of general virology. 2012;93(Pt 3):494 503 .

6. Wang C, Horby P, Hayden F, Gao G. A novel coronavirus outbreak of global health concern. Lancet. 2020;395(10223):470-3.

7. Jiang F, Deng L, Zhang L, Cai Y, Cheung C, Xia Z. Review of the clinical characteristics of Coronavirus disease 2019 (COVID-19). J Gen Intern Med. 2020;4:1-5.

8. Lu H. Drug treatment options for the 2019-new coronavirus (2019-nCoV). Bioscience trends. 2020;14:69-71.

9. Wu Z, McGoogan J. Characteristics of and important lessons from the coronavirus disease 2019 (COVID-19) outbreak in China: summary of a report of 72314 cases from the Chinese Center for Disease Control and Prevention. Jama. 2020;323:1239.

10. Rothan H, Byrareddy S. The epidemiology and pathogenesis of coronavirus disease (COVID-19) outbreak. J Autoimmun. 2020;102433

11. Organization WH. Coronavirus disease 2019 (COVID-19): situation report, 51. 2020.

12. Wang D, Hu B, Hu C, Zhu F, Liu X, Zhang J, et al. Clinical characteristics of 138 hospitalized patients with 2019 novel coronavirus-infected pneumonia in Wuhan, China. Jama. 2020

13. Lu Q, Shi Y. Coronavirus disease (COVID-19) and neonate: what neonatologist need to know. J Med Virol. 2020.

14. Zu Z, Jiang M, Xu P, Chen W, Ni Q, Lu G, et al. Coronavirus disease 2019 (COVID-19): a perspective from China. Radiology. 2020;200490.

15. Ai T, Yang Z, Hou H, Zhan C, Chen C, Lv W, et al. Correlation of chest CT and RT-PCR testing in coronavirus disease 2019 (COVID-19) in China: a report of 1014 cases. Radiology. 2020;200642.

16. Ng M, Lee E, Yang J, Yang F, Li X, Wang H, et al. Imaging profile of the COVID-19 infection: radiologic findings and literature review. Radiology: Cardiothoracic Imaging. 2020;2(1): e200034.

17. Mann GJ. Use of Remdesivir in COVID-19.

18. Hillaker E, Belfer JJ, Bondici A, Murad H, Dumkow LE. Delayed initiation of Remdesivir in a COVID-19-positive patient. The Journal of Human Pharmacology and Drug Therapy: Pharmacotherapy; 2020.

19. Siddell S, Wege H, Ter Meulen V. The biology of coronaviruses. J Gen Virol. 1983;64(4):761-76.

20. Jia X, Yin C, Lu S, Chen Y, Liu Q, Bai J, et al. Two things about COVID-19 might need attention. 2020.

21. Del Rio C, Malani PN. COVID-19 — new insights on a rapidly changing epidemic. Jama. 2020.

22. Jia X, Yin C, Lu S, Chen Y, Liu Q, Bai J, et al. Two things about COVID-19 might need attention. 2020.

23. Lukassen S, Chua RL, Trefzer T, Kahn NC, Schneider MA, Muley T, et al. SARS-CoV-2 receptor ACE2 and TMPRSS2 are predominantly expressed in a transient secretory cell type in subsegmental bronchial branches. bioRxiv. 2020.

24. Burkard C, Verheije MH, Wicht O, van Kasteren SI, van Kuppeveld FJ, Haagmans BL, et al. Coronavirus cell entry occurs through the endo-/lysosomal pathway in a proteolysis-dependent manner. PLoS pathogens. 2014;10(11).

25. Yang N, Shen H-M. Targeting the Endocytic pathway and autophagy process as a Novel therapeutic strategy in COVID-19. Int J Biol Sci. 2020;16(10):1724-31.

26. Shereen MA, Khan S, Kazmi A, Bashir N, Siddique R. COVID19 infection: origin, transmission, and characteristics of human coronaviruses. J Adv Res. 2020;24:91-8.

27. Izaguirre G. The Proteolytic regulation of virus cell entry by Furin and other Proprotein Convertases. Viruses. 2019;11(9):837.

28. Hoffmann M, Kleine-Weber H, Schroeder S, Krüger N, Herrler T, Erichsen S, et al. SARS-CoV-2 cell entry depends on ACE2 and TMPRSS 2 and is blocked by a clinically proven protease inhibitor. Cell. 2020;181:271-280.e8.

29. Heurich A, Hofmann-Winkler H, Gierer S, Liepold T, Jahn O, Pöhlmann S. TMPRSS2 and ADAM17 cleave ACE2 differentially and only proteolysis by TMPRSS2 augments entry driven by the severe acute respiratory syndrome coronavirus spike protein. J Virol. 2014;88(2):1293-307.

30. Duan K, Liu B, Li C, Zhang H, Yu T, Qu J, et al. Effectiveness of convalescent plasma therapy in severe COVID-19 patients. Proc Natl Acad Sci. 2020;117:9490-6.

31. Tanne JH. Covid-19: FDA approves use of convalescent plasma to treat critically ill patients. Bmj. 2020;368:m1256.

32. Chou H-W, Wang C-H, Lin L-Y, Chi N-H, Chou N-K. Yu H-Y, et al. Journal of Critical Care: Prognostic factors for heart recovery in adult patients with acute fulminant myocarditis and cardiogenic shock supported with extracorporeal membrane oxygenation; 2020.

33. Zhang H, Penninger J, Li Y, Zhong N, Slutsky A. Angiotensinconverting enzyme 2 (ACE2) as a SARS-CoV-2 receptor: molecular mechanisms and potential therapeutic target. Intensive Care Med. 2020:1-5.

34. Chen L, Xiong J, Bao L, Shi Y. Convalescent plasma as a potential therapy for COVID-19. Lancet Infect Dis. 2020;20(4):398400.

35. Xu H, Zhong L, Deng J, Peng J, Dan H, Zeng X, et al. High expression of ACE2 receptor of 2019-nCoV on the epithelial cells of oral mucosa. International Journal of Oral Science. 2020;12(1): $1-5$.

36. Zou X, Chen K, Zou J, Han P, Hao J, Han Z. Single-cell RNA-seq data analysis on the receptor ACE2 expression reveals the potential risk of different human organs vulnerable to $2019-\mathrm{nCoV}$ infection. Frontiers of medicine. 2020:1-8.

37. Bao L, Deng W, Huang B, Gao H, Liu J, Ren L, et al. The Pathogenicity of SARS-CoV-2 in hACE2 Transgenic Mice. bioRxiv. 2020. 
38. Clerkin KJ, Fried JA, Raikhelkar J, Sayer G, Griffin JM, Masoumi A, et al. Coronavirus disease 2019 (COVID-19) and cardiovascular disease. Circulation. 2020.

39. Hanff TC, Harhay MO, Brown TS, Cohen JB, Mohareb AM. Is there an association between COVID-19 mortality and the reninangiotensin system - a call for epidemiologic investigations. Clin Infect Dis. 2020.

40. Fang L, Karakiulakis G, Roth M. Are patients with hypertension and diabetes mellitus at increased risk for COVID-19 infection? The lancet respiratory medicine. 2020.

41. Day M. Covid-19: ibuprofen should not be used for managing symptoms, say doctors and scientists: British Medical Journal Publishing Group; 2020.

42. Chamsi-Pasha MA, Shao Z, Tang WW. Angiotensin-converting enzyme 2 as a therapeutic target for heart failure. Current heart failure reports. 2014;11(1):58-63.

43. Ruan Q, Yang K, Wang W, Jiang L, Song J. Clinical predictors of mortality due to COVID-19 based on an analysis of data of 150 patients from Wuhan, China. Intensive Care Med. 2020:1-3.

44. Tan W, Aboulhosn J. The cardiovascular burden of coronavirus disease 2019 (COVID-19) with a focus on congenital heart disease. Int J Cardiol. 2020;309:70-7.

45. Yao TT, Qian JD, Zhu WY, Wang Y, Wang GQ. A systematic review of lopinavir therapy for SARS coronavirus and MERS coronavirus - a possible reference for coronavirus disease-19 treatment option. J Med Virol. 2020;92:556-63.

46. El Ezzi AA, Clawson JM, El-Saidi MA, Zaidan WR, Kovash A, Orellana J, et al. Association of Angiotensin I Converting Enzyme Insertion/287 bp deletion polymorphisms and proliferative prostatic diseases among Lebanese men. Prostate Cancer. 2020;2020.

47. Ramezani M, Zavattaro E, Sadeghi M. Angiotensin-converting enzyme gene insertion/deletion polymorphism and susceptibility to psoriasis: a systematic review and meta-analysis. BMC Medical Genetics. 2020;21(1):8.

48. Worobey CC, Fisher ND, Cox D, Forman JP, Curhan GC. Genetic polymorphisms and the risk of accelerated renal function decline in women. PloS one. 2009;4(3).

49. Delanghe JR, Speeckaert MM, De Buyzere ML. The host's angiotensin-converting enzyme polymorphism may explain epidemiological findings in COVID-19 infections. Clinica Chimica Acta; International Journal of Clinical Chemistry. 2020;505:192.

50. Aljofan M, Gaipov A. COVID-19 Treatment: The Race Against Time. Electron J Gen Med. 2020; 17 (6): em227. 2020.

51. Singh AK, Singh A, Shaikh A, Singh R, Misra A. Chloroquine and hydroxychloroquine in the treatment of COVID-19 with or without diabetes: a systematic search and a narrative review with a special reference to India and other developing countries. Clinical Research \& Reviews: Diabetes \& Metabolic Syndrome; 2020.

52. Wilson S, Greer B, Hooper J, Zijlstra A, Walker B, Quigley J, et al. The membrane-anchored serine protease, TMPRSS2, activates PAR-2 in prostate cancer cells. Biochem J. 2005;388(3): 967-72.

53. Zhirnov O, Klenk H, Wright P. Aprotinin and similar protease inhibitors as drugs against influenza. Antivir Res. 2011;92(1): 27-36.

54. Alhenc-Gelas F, Drueke TB. Blockade of SARS-CoV-2 infection by recombinant soluble ACE2. Kidney Int. 2020;97:1091-3.

55. Ishikawa $\mathrm{Y}$, Maeda M, Pasham M, Aguet F, Tacheva-Grigorova SK, Masuda T, et al. Role of the clathrin adaptor PICALM in normal hematopoiesis and polycythemia vera pathophysiology. Haematologica. 2015;100(4):439-51.

56. Luzio JP, Parkinson MD, Gray SR, Bright NA. The delivery of endocytosed cargo to lysosomes. Portland Press Ltd.

57. Andersen KG, Rambaut A, Lipkin WI, Holmes EC, Garry RF. The proximal origin of SARS-CoV-2. Nat Med. 2020;26(4):450 2.
58. Yin C. Genotyping coronavirus SARS-CoV-2: methods and implications. arXiv preprint arXiv:200310965. 2020.

59. Zhou D, Dai S-M, Tong Q. COVID-19: a recommendation to examine the effect of hydroxychloroquine in preventing infection and progression. J Antimicrob Chemother. 2020;75:1667-70.

60. Qiu Z, Hingley ST, Simmons G, Yu C, Sarma JD, Bates P, et al. Endosomal proteolysis by cathepsins is necessary for murine coronavirus mouse hepatitis virus type 2 spike-mediated entry. $\mathrm{J}$ Virol. 2006;80(12):5768-76.

61. Coutard B, Valle C, de Lamballerie X, Canard B, Seidah N, Decroly E. The spike glycoprotein of the new coronavirus 2019nCoV contains a furin-like cleavage site absent in $\mathrm{CoV}$ of the same clade. Antivir Res. 2020;176:104742.

62. Sheybani Z, Dokoohaki MH, Negahdaripour M, Dehdashti M, Zolghadr H, Moghadami M, et al. The role of folic acid in the management of respiratory disease caused by COVID-19. 2020.

63. Deng L, Li C, Zeng Q, Liu X, Li X, Zhang H, et al. Arbidol combined with LPV/r versus LPV/r alone against Corona Virus Disease 2019: A retrospective cohort study. J Infect 2020.

64. Blaising J, Lévy P, Polyak S, Stanifer M, Boulant S, Pécheur E. Arbidol inhibits viral entry by interfering with clathrin-dependent trafficking. Antivir Res. 2013;100(1):215-9.

65. Li H, Zhou Y, Zhang M, Wang H, Zhao Q, Liu J. Updated approaches against SARS-CoV-2. Antimicrobial agents and chemotherapy. 2020;64(6).

66. Kuzu O, Toprak M, Noory M, Robertson G. Effect of lysosomotropic molecules on cellular homeostasis. Pharmacol Res. 2017;117:177-84.

67. de Duve C, de Barsy T, Poole B, Trouet A, Tulkens P, Van Hoof F. Lysosomotropic agents. Biochem Pharmacol. 1974;23(18): 2495-531.

68. Wernersson S, Riihimäki M, Pejler G, Waern I. Equine airway mast cells are sensitive to cell death induced by Lysosomotropic agents. Scand J Immunol. 2017;85(1):30-4.

69. Schrezenmeier E, Dörner T. Mechanisms of action of hydroxychloroquine and chloroquine: implications for rheumatology. Nat Rev Rheumatol. 2020;16:155-66.

70. Gautret P, Lagier J-C, Parola P, Meddeb L, Mailhe M, Doudier B, et al. Hydroxychloroquine and azithromycin as a treatment of COVID-19: results of an open-label non-randomized clinical trial. Int J Antimicrob Agents. 2020;105949.

71. Chen Z, Hu J, Zhang Z, Jiang S, Han S, Yan D, et al. Efficacy of hydroxychloroquine in patients with COVID-19: results of a randomized clinical trial. MedRxiv. 2020.

72. Wang H, Yuan X, Sun Y, Mao X, Meng C, Tan L, et al. Infectious bronchitis virus entry mainly depends on clathrin mediated endocytosis and requires classical endosomal/lysosomal system. Virology. 2019;528:118-36.

73. Yazdany J, Kim A. Use of Hydroxychloroquine and Chloroquine during the COVID-19 pandemic: what every clinician should know. Ann Intern Med. 2020;172:754-5.

74. Yao X, Ye F, Zhang M, Cui C, Huang B, Niu P, et al. In vitro antiviral activity and projection of optimized dosing design of hydroxychloroquine for the treatment of severe acute respiratory syndrome coronavirus 2 (SARS-CoV-2). Clin Infect Dis. 2020.

75. Cure E, Cure MC. Can dapagliflozin have a protective effect against COVID-19 infection? A hypothesis Diabetes \& Metabolic Syndrome. 2020;14(4):405-6.

76. Anastasopoulou S, Mouzaki A. The biology of SARS-CoV-2 and the ensuing COVID-19. 2020.

77. Zhou N, Pan T, Zhang J, Li Q, Zhang X, Bai C, et al. Glycopeptide antibiotics potently inhibit cathepsin L in the late endosome/ lysosome and block the entry of Ebola virus, Middle East respiratory syndrome coronavirus (MERS-CoV), and severe acute respiratory syndrome coronavirus (SARS-CoV). J Biol Chem. 2016;291(17):9218-32. 
78. Matsuyama S, Kawase M, Nao N, Shirato K, Ujike M, Kamitani $\mathrm{W}$, et al. The inhaled corticosteroid ciclesonide blocks coronavirus RNA replication by targeting viral NSP15. bioRxiv. 2020.

79. Touret F, Gilles M, Barral K, Nougairède A, Decroly E, de Lamballerie X, et al. In vitro screening of a FDA approved chemical library reveals potential inhibitors of SARS-CoV-2 replication. bioRxiv. 2020.

80. Guntuku L, Gangasani J, Thummuri D, Borkar R, Manavathi B, Ragampeta S, et al. IITZ-01, a novel potent lysosomotropic autophagy inhibitor, has single-agent antitumor efficacy in triplenegative breast cancer in vitro and in vivo. Oncogene. 2019;38(4):581-95.

81. Cascella M, Rajnik M, Cuomo A, Dulebohn S, Di Napoli R. Features, evaluation and treatment coronavirus (COVID-19). InStatPearls [Internet] StatPearls Publishing. 2020.

82. Ahmed T, Noman M, Almatroudi A, Shahid M, Khurshid M, Tariq F, et al. Linked with Pneumonia in China: Current Status and Future Prospects. 2019:2020.

83. Al-Mulla HM, Turrell L, Smith NM, Payne L, Baliji S, Züst R, et al. Competitive fitness in coronaviruses is not correlated with size or number of double-membrane vesicles under reducedtemperature growth conditions. MBio. 2014;5(2):e01107-13.

84. Narayanan N, Nair D. Vitamin B12 may inhibit RNA-dependentRNA polymerase activity of NSP12 from the COVID-19 virus. 2020.

85. Venkataraman S, Prasad B, Selvarajan R. RNA dependent RNA polymerases: insights from structure. Function and Evolution Viruses. 2018;10(2):76.

86. Walls A, Park Y, Tortorici M, Wall A, McGuire A, Veesler D. Structure, function, and antigenicity of the SARS-CoV-2 spike glycoprotein. Cell. 2020;181:281-292.e6.

87. de Wit E, van Doremalen N, Falzarano D, Munster V. SARS and MERS: recent insights into emerging coronaviruses. Nat Rev Microbiol. 2016;14(8):523-34.

88. Liu W, Li H. COVID-19 disease: ORF8 and surface glycoprotein inhibit Heme metabolism by binding to Porphyrin. 2020.

89. Read R. Flawed methods in "COVID-19: attacks the 1-Beta chain of hemoglobin and captures the Porphyrin to inhibit human Heme metabolism". 2020.

90. Abrahams L. Covid-19: acquired acute porphyria hypothesis. 2020.

91. Chen H, Zhang Z, Wang L, Huang Z, Gong F, Li X, et al. First Clinical Study Using HCV Protease Inhibitor Danoprevir to Treat Naive and Experienced COVID-19 Patients. medRxiv. 2020.

92. Cao B, Wang Y, Wen D, Liu W, Wang J, Fan G, et al. A trial of lopinavir-ritonavir in adults hospitalized with severe Covid-19. N Engl J Med. 2020;382:1787-99.

93. Lai C, Shih T, Ko W, Tang H, Hsueh P. Severe acute respiratory syndrome coronavirus 2 (SARS-CoV-2) and corona virus disease2019 (COVID-19): the epidemic and the challenges. Int J Antimicrob Agents. 2020;55(3):105924.

94. Yamamoto N, Matsuyama S, Hoshino T, Yamamoto N. Nelfinavir inhibits replication of severe acute respiratory syndrome coronavirus 2 in vitro. bioRxiv. 2020.

95. Zhang L, Liux LY. Potential interventions for novel coronavirus in China: a systematic review. J Med Virol. 2020.

96. Dutta K, Shityakov S, Morozova O, Khalifa I, Zhang J, Panda A, et al. Beclabuvir can inhibit the RNA-dependent RNA polymerase of newly emerged novel coronavirus (SARS-CoV-2). 2020.

97. Scholz M, Derwand R. Does zinc supplementation enhance the clinical efficacy of Chloroquine/Hydroxychloroquine to win todays Battle against COVID-19? 2020.

98. Gordon C, Tchesnokov E, Feng J, Porter D. Gotte M. Journal of Biological Chemistry: The antiviral compound remdesivir potently inhibits RNA-dependent RNA polymerase from Middle East respiratory syndrome coronavirus; 2020.
99. Wang M, Cao R, Zhang L, Yang X, Liu J, Xu M, et al. Remdesivir and chloroquine effectively inhibit the recently emerged novel coronavirus (2019-nCoV) in vitro. Cell Res. 2020;30(3):269-71.

100. Choy K, Wong A, Kaewpreedee P, Sia S, Chen D, Hui K, et al. Remdesivir, lopinavir, emetine, and homoharringtonine inhibit SARS-CoV-2 replication in vitro. Antivir Res. 2020;104786.

101. Grein J, Ohmagari N, Shin D, Diaz G, Asperges E, Castagna A, et al. Compassionate use of remdesivir for patients with severe Covid-19. N Engl J Med. 2020;382(24):2327-36.

102. Wang Y, Zhang D, Du G, Du R, Zhao J, Jin Y, et al. Remdesivir in adults with severe COVID-19: a randomised, double-blind, placebo-controlled, multicentre trial. Lancet. 2020;395:1569-78.

103. Beigel JH, Tomashek KM, Dodd LE, Mehta AK, Zingman BS, Kalil AC, et al. Remdesivir for the treatment of Covid-19-preliminary report. N Engl J Med. 2020.

104. Shiraki K, Daikoku T. Favipiravir, an anti-influenza drug against life-threatening RNA virus infections. Pharmacol Ther. 2020;107512.

105. Schwarz S, Wang K, Yu W, Sun B, Schwarz W. Emodin inhibits current through SARS-associated coronavirus 3a protein. Antivir Res. 2011;90(1):64-9.

106. Yang Y, Islam M, Wang J, Li Y, Chen X. Traditional Chinese medicine in the treatment of patients infected with 2019-new Coronavirus (SARS-CoV-2): a review and perspective. Int $\mathrm{J}$ Biol Sci. 2020;16(10):1708-17.

107. Caly L, Druce J, Catton M, Jans D, Wagstaff K. The FDAapproved drug Ivermectin inhibits the replication of SARS-CoV2 in vitro. Antivir Res. 2020;104787.

108. Patel A, Desai S. Ivermectin in COVID-19 Related Critical Illness. Available at SSRN 3570270. 2020

109. Shah B, Modi P, Sagar S. In silico studies on therapeutic agents for COVID-19: drug repurposing approach. Life Sci. 2020;252: 117652.

110. Elfiky AA. Anti-HCV, nucleotide inhibitors, repurposing against COVID-19. Life Sci. 2020;117477.

111. Xu Z, Yao H, Shen J, Wu N, Xu Y, Lu X, et al. Nelfinavir is active against SARS-CoV-2 in Vero E6 cells. 2020.

112. Chen $\mathrm{C}$, Huang J, Cheng $\mathrm{Z}$, Wu J, Chen S, Zhang Y, et al. Favipiravir versus Arbidol for COVID-19: a randomized clinical trial. MedRxiv. 2020.

113. Stebbing J, Phelan A, Griffin I, Tucker C, Oechsle O, Smith D, et al. COVID-19: combining antiviral and anti-inflammatory treatments. Lancet Infect Dis. 2020;20(4):400-2.

114. Xu Z, Yao H, Shen J, Wu N, Xu Y, Lu X, et al. Nelfinavir is active against SARS-CoV-2 in Vero E6 cells. ChemRxiv. 2020.

115. Mosaddeghi P, Negahdaripour M, Dehghani Z, Farahmandnejad M, Moghadami M, Nezafat N, et al. Therapeutic approaches for COVID-19 based on the dynamics of interferon-mediated immune responses. 2020

116. Taghizadeh-Hesary F, Akbari H. The powerful immune system against powerful COVID-19: a hypothesis. Med Hypotheses. 2020;109762.

117. Wong C, Ho CY, Li E, Lam C. Elevation of proinflammatory cytokine (IL-18, IL-17, IL-12) and Th2 cytokine (IL-4) concentrations in patients with systemic lupus erythematosus. Lupus. 2000;9(8):589-93.

118. Makhija R, Kingsnorth AN. Cytokine storm in acute pancreatitis. J Hepato-Biliary-Pancreat Surg. 2002;9(4):401-10.

119. Xu X, Han M, Li T, Sun W, Wang D, Fu B, et al. Effective treatment of severe COVID-19 patients with tocilizumab. ChinaXiv. 2020;202003(00026):v1.

120. Chiappelli F, Khakshooy A, Greenberg G. CoViD-19 immunopathology and immunotherapy. Bioinformation. 2020;16(3):219 22 .

121. Chan JF-W, Yuan S, Kok K-H, To KK-W, Chu H, Yang J, et al. A familial cluster of pneumonia associated with the 2019 novel 
coronavirus indicating person-to-person transmission: a study of a family cluster. Lancet. 2020;395(10223):514-23.

122. Xu Z, Shi L, Wang Y, Zhang J, Huang L, Zhang C, et al. Pathological findings of COVID-19 associated with acute respiratory distress syndrome. Lancet Respir Med. 2020;8(4):420-2.

123. Wu X, Tian J, Wang S. Insight into non-pathogenic Th17 cells in autoimmune diseases. Front Immunol. 2018;9:1112.

124. Caproni M, Antiga E, Melani L, Volpi W, Del Bianco E, Fabbri P. Serum levels of IL-17 and IL-22 are reduced by etanercept, but not by acitretin, in patients with psoriasis: a randomized-controlled trial. J Clin Immunol. 2009;29(2):210-4.

125. Bashyam AM, Feldman SR. Dermatology and the COVID-19 Pandemic Dermatology and the COVID-19 Pandemic.

126. Gielen V, Johnston SL, Edwards MR. Azithromycin induces antiviral responses in bronchial epithelial cells. Eur Respir J. 2010;36(3):646-54.

127. Ray PD, Huang B-W, Tsuji Y. Reactive oxygen species (ROS) homeostasis and redox regulation in cellular signaling. Cell Signal. 2012;24(5):981-90.

128. Guillin OM, Vindry C, Ohlmann T, Chavatte L. Selenium, selenoproteins and viral infection. Nutrients. 2019;11(9):2101.

129. Nasi A, McArdle S, Gaudernack G, Westman G, Melief C, Arens $\mathrm{R}$, et al. Proteasome and reactive oxygen species dysfunction as risk factors for SARS-CoV infection; consider N-acetylcystein as therapeutic intervention. 2020.

130. Lang ZW, Zhang LJ, Zhang SJ, Meng X, Li JQ, Song CZ, et al. A clinicopathological study of three cases of severe acute respiratory syndrome (SARS). Pathology. 2003;35(6):526-31.

131. Jose RJ, Manuel A. COVID-19 cytokine storm: the interplay between inflammation and coagulation. Lancet Respir Med. 2020;8: e46-7.

132. Takano H. Pulmonary surfactant itself must be a strong defender against SARS-CoV-2. Med Hypotheses. 2020;110020.

133. Ritchie AI, Singanayagam A. Immunosuppression for hyperinflammation in COVID-19: a double-edged sword? Lancet. 2020;395(10230):1111.

134. Diao B, Wang C, Tan Y, Chen X, Liu Y, Ning L, et al. Reduction and functional exhaustion of $\mathrm{T}$ cells in patients with coronavirus disease 2019 (COVID-19). Medrxiv. 2020.

135. Jin H-T, Ahmed R, Okazaki T. Role of PD-1 in regulating T-cell immunity. Negative co-receptors and ligands: Springer; 2010. p. 17-37.

136. Olive D, inventor; Google Patents, assignee. PD-1 antibodies and PD-L1 antibodies and uses thereof 2014.

137. Mehta P, McAuley DF, Brown M, Sanchez E, Tattersall RS, Manson JJ. COVID-19: consider cytokine storm syndromes and immunosuppression. Lancet. 2020;395(10229):1033-4.

138. Hawill B, Geraci J. Candidate drug, Dupilumab, to mitigate COVID-19 patients with severe acute respiratory Syn-drome by mitigating cytokine storm. 2020.

139. Liu J, Cao R, Xu M, Wang X, Zhang $\mathrm{H}, \mathrm{Hu} \mathrm{H}$, et al. Hydroxychloroquine, a less toxic derivative of chloroquine, is effective in inhibiting SARS-CoV-2 infection in vitro. Cell discovery. 2020;6(1):1-4.

140. Iglesias J, Sathiraju S, Marik PE. Severe systemic inflammatory response syndrome with shock and ARDS resulting from Still's disease: clinical response with high-dose pulse methylprednisolone therapy. Chest. 1999;115(6):1738-40.

141. Vahedi E, Ghanei M, Ghazvini A, Azadi H, Izadi M, Panahi Y, et al. The clinical value of two combination regimens in the Management of Patients Suffering from Covid-19 pneumonia: a single centered, retrospective, observational study. DARU Journal of Pharmaceutical Sciences. 2020:1-10.

142. Chorin E, Dai M, Shulman E, Wadhwani L, Bar-Cohen R, Barbhaiya C, et al. The QT interval in patients with COVID-19 treated with hydroxychloroquine and azithromycin. Nat Med. 2020:1-2.

143. Veronese N, Demurtas J, Yang L, Tonelli R, Barbagallo M, Lopalco P, et al. Use of corticosteroids in Coronavirus disease 2019 pneumonia: a systematic review of the literature. Frontiers in medicine. 2020;7:170.

144. Russell CD, Millar JE, Baillie JK. Clinical evidence does not support corticosteroid treatment for 2019-nCoV lung injury. Lancet. 2020;395(10223):473-5.

145. Panel C-TG. Coronavirus disease 2019 (COVID-19) treatment guidelines. Health NIo, editor: In; 2020.

146. Oldstone MB, Rosen H. Cytokine storm plays a direct role in the morbidity and mortality from influenza virus infection and is chemically treatable with a single sphingosine-1-phosphate agonist molecule. Sphingosine-1-Phosphate Signaling in Immunology and Infectious Diseases: Springer; 2014. p. 129-47.

147. Prakash H, Bandapalli OR, Jain A, Kleuser B. Ceramide-1 phosphate as multi-targets immune adjuvant for controlling Covid-19 infection: perspective. 2020.

148. De Sanctis JB, Garmendia JV, Moreno D, Larocca N, Mijares M, Di Giulio C, et al. Pharmacological modulation of Th17. Recent Patents Inflamm Allergy Drug Discov. 2009;3(2):149-56.

149. Rawlings JS, Rosler KM, Harrison DA. The JAK/STAT signaling pathway. J Cell Sci. 2004;117(8):1281-3.

150. Dastan F, Nadji SA, Saffaei A, Marjani M, Moniri A, Jamaati H, et al. Subcutaneous administration of interferon beta-1a for COVID-19: a non-controlled prospective trial. Int Immunopharmacol. 2020;106688.

151. Hung IF-N, Lung K-C, Tso EY-K, Liu R, Chung TW-H, Chu M$\mathrm{Y}$, et al. Triple combination of interferon beta- $1 \mathrm{~b}$, lopinavir-ritonavir, and ribavirin in the treatment of patients admitted to hospital with COVID-19: an open-label, randomised, phase 2 trial. Lancet. 2020;395(10238):1695-704.

152. Xu Y, Li X, Zhu B, Liang H, Fang C, Gong $\mathrm{Y}$, et al. Characteristics of pediatric SARS-CoV-2 infection and potential evidence for persistent fecal viral shedding. Nat Med. 2020;26(4): $502-5$.

153. Sallard E, Lescure F-X, Yazdanpanah Y, Mentre F, PeifferSmadja N, Florence A, et al. Type 1 interferons as a potential treatment against COVID-19. Antivir Res. 2020;104791.

154. Zhang R, Wang X, Ni L, Di X, Ma B, Niu S, et al. COVID-19: melatonin as a potential adjuvant treatment. Life Sci. 2020;117583.

155. Zhang R, Wang X, Ni L, Di X, Ma B, Niu S, et al. COVID-19: melatonin as a potential adjuvant treatment. Life Sci. $2020 ; 117583$.

156. Fintelman-Rodrigues N, Sacramento CQ, Lima CR, da Silva FS, Ferreira A, Mattos M, et al. Atazanavir inhibits SARS-CoV-2 replication and pro-inflammatory cytokine production. bioRxiv. 2020.

157. Cortegiani A, Ingoglia G, Ippolito M, Giarratano A, Einav S. A systematic review on the efficacy and safety of chloroquine for the treatment of COVID-19. J Crit Care. 2020.

158. Tootee A, Esfahani EN, Larijani B. Diabetes management during Ramadan amid Covid-19 pandemic. DARU Journal of Pharmaceutical Sciences. 2020:1-4.

159. Schrom E, Huber M, Aneja M, Dohmen C, Emrich D, Geiger J, et al. Translation of angiotensin-converting enzyme 2 upon liverand lung-targeted delivery of optimized chemically modified mRNA. Molecular Therapy-Nucleic Acids. 2017;7:350-65.

160. Kaksonen M, Roux A. Mechanisms of clathrin-mediated endocytosis. Nat Rev Mol Cell Biol. 2018;19(5):313-26.

161. Xiao HD, Fuchs S, Campbell DJ, Lewis W, Dudley SC Jr, Kasi $\mathrm{VS}$, et al. Mice with cardiac-restricted angiotensin-converting enzyme (ACE) have atrial enlargement, cardiac arrhythmia, and sudden death. Am J Pathol. 2004;165(3):1019-32. 
162. Gupta S, Markham DW, Drazner MH, Mammen PP. Fulminant myocarditis. Nature clinical practice cardiovascular medicine. 2008;5(11):693-706.

163. Tanaka K. The proteasome: overview of structure and functions. Proceedings of the Japan Academy, Series B. 2009;85(1):12-36.

164. Gounden V, Jialal I. Acute porphyria. 2019.

165. Pross S, Lefkowitz D. Cell-mediated immunity. 2007.

166. Fitch FW. Cell-mediated immunity. 1998.
167. Zhang J-M, An J. Cytokines, inflammation and pain. Int Anesthesiol Clin. 2007;45(2):27-37.

168. Storz G, Imlayt JA. Oxidative stress. Curr Opin Microbiol. 1999;2(2):188-94.

Publisher's note Springer Nature remains neutral with regard to jurisdictional claims in published maps and institutional affiliations. 